\title{
From Forager to Cultivator: A Case Study in the Zagros Mountains of Iran
}

\author{
Jonathan Adam Baines ${ }^{1}$ \\ ${ }^{1}$ Tübingen University, Institut für Naturwissenschaftliche Archäologie, 23 Rümelinstrasse, 72070 Tübingen, Germany. \\ Correspondence: Jonathan Adam Baines, Tübingen University, Institut für Naturwissenschaftliche Archäologie, 23 \\ Rümelinstrasse, 72070 Tübingen, Germany.
}

Received: August 31, 2015

Accepted: September 11, 2015

Available online: October 30, 2015

doi:10.11114/ijsss.v3i6.1183

URL: http://dx.doi.org/10.11114/ijsss.v3i6.1183

\begin{abstract}
This paper examines the early aceramic Neolithic botanic assemblage from Chogha Golan, Iran, for signs of cultivation. Based on the presumption that people's engagement with the local vegetation altered due to a changing mode of residence and mobility during that period, its record of edible and useful plants ought to look different compared to that of the site's later assemblages that include domesticated emmer. The study involved data from coeval sites in the region and three Palaeolithic outliers, including Ghar-e Boof, a Rostamian cave occupation in the Zagros Mountains. Though the information does not refute efforts at cultivation at the site during the midden's initial occupation, the analyses rather suggest that a realignment of hunter-gatherer traditions took place, with local plant exploitation targeting a wider breadth in the landscape. Inherited subsistence strategies were adapted to the new human and natural setting inhabited, in which high yield legumes and grasses dominated procurement and became the focus of the incipient agricultural transformations underway.
\end{abstract}

Keywords: Archaeobotany; Zagros Mountains; aceramic Neolithic

\section{Introduction}

The Tübingen Iranian Stone Age Research Project (TISARP) was founded to address gaps in the Iranian Palaeolithic record. These blanks include the regional development of lithic technology, dispersion of population and Palaeolithic occupation (Conard 2011; Ghasidian 2014; Heydari-Guran 2014). Though the region is often mentioned in archaeobotany alongside the Levant as a locus for wild exploitation and pre-domestication cultivation, few sites are actually recorded (Colledge 2004; Martinoli 2004; for a comparable research see Fuller 2012a and Willcox 2013). Therefore to complement TISARP's efforts, the archaeobotanical analysis was undertaken on two sites excavated between 2006 and 2011 in the Zagros Mountains. Ghar-e Boof is a Rostamian, or Upper early, cave site with occupation horizons dating between to 36000 and 31000 BP. Chogha Golan is an aceramic tell site whose hunter-gatherer sequence begins at the end of the Younger Dryas (about $10650 \mathrm{BP}$ ) and ends about $9000 \mathrm{BP}$. Both sites have been partially published, their archaeobotanic examination is still ongoing (Riehl et al. 2011 and 2013, Baines 2014). This article addresses the question: did hunter-gatherer behaviour turn from "passive recipients of the environment" (Rowley-Conwy 2011 p.851) to "ecosystem engineers" near the end of the Palaeolithic (Jones et al. 1994)? The archaeobotanic assemblages of Ghar e Boof, Chogha Golan and a few selected Epi-Palaeolithic and pre-pottery Neolithic A (PPNA) sites in Southwestern Asia (see figure 1), are examined for signs of cultivation and alterations in the plant communities. Factors complicating this question are the people's mode of residence and mobility, their community dynamics and the palaeo-environmental setting inhabited with its own climate conditions.

\section{Site Descriptions}

The Zagros Mountains stretch from Armenia Southwards along the Western border of Iran to the Gulf coast and covers a wide variety of landscapes and ecological zones. Its higher elevations reach beyond the tree line up to $4000 \mathrm{~m}$ a.s.l. and are surrounded by widely spreading foothills and intermountain valleys. Both sites are situated near year-round flowing water and close to marshy areas, with a surrounding rocky and rough terrain, offering plentiful stone, plant and animal sources.

Ghar-e Boof is situated in one of these intermountain valleys: the Dasht-e-Rostam, in the Fars Province. The area receives most of its rainfall during winter (annually about $450 \mathrm{~mm}$.) with almost no precipitation the rest of the year 
(Heydari-Guran 2007). The valley forms a transition between the lowland and foothill (between 200 and $800 \mathrm{~m}$ a.s.1.) and the mountain zones (800 to over 2000 m.a.s.1.) according to van Zeist's (2008) vegetation zones of the Zagros. The limestone cave lies at $650 \mathrm{~m}$ a.s.1 and faces north-northeast across the valley floor 100 metres below. The recovered stone tools and debitage are best described as Rostamian, a lithic typology that stands apart from the region's otherwise common Baradostian assemblages (Ghasidian 2014). The cave's occupation was temporary, intensive and without domestic features like hearths or permanent structures. The location of the site, at the intersection of several varied ecological zones, provides diverse and seasonally abundant resources. A suite of palynological studies from lake cores suggests the existence of this wide botanic diversity in the region during the late Pleistocene (see Hole 1978 and Bottema 1993 for lake Zeribar; see Moslimany 1987 and Wasylikowa 2005 for lakes Maharlou and Urmia; and see Djamali 2008 and van Zeist 1967 for lake Mirabad).

Chogha Golan is situated $600 \mathrm{~km}$ northwest of Ghar-e Boof in the Ilam province in the Zagros foothills. It lies in the Kanjan Cham valley overlooking the Mehran plain and is at $485 \mathrm{~m}$ a.s.1. Only samples from the sites' first occupation were examined. Excavation at this site has focussed on the later phases of occupation, limiting interpretation of this midden. Its later horizons feature in the comparative part of this study together with the other selected Southwestern Asian sites. Though use was made of the same datasets, as will be seen below, my conclusions on this horizon differ from earlier interpretations of the site and its place within the development of agricultural systems in this region (Riehl et al. 2013).

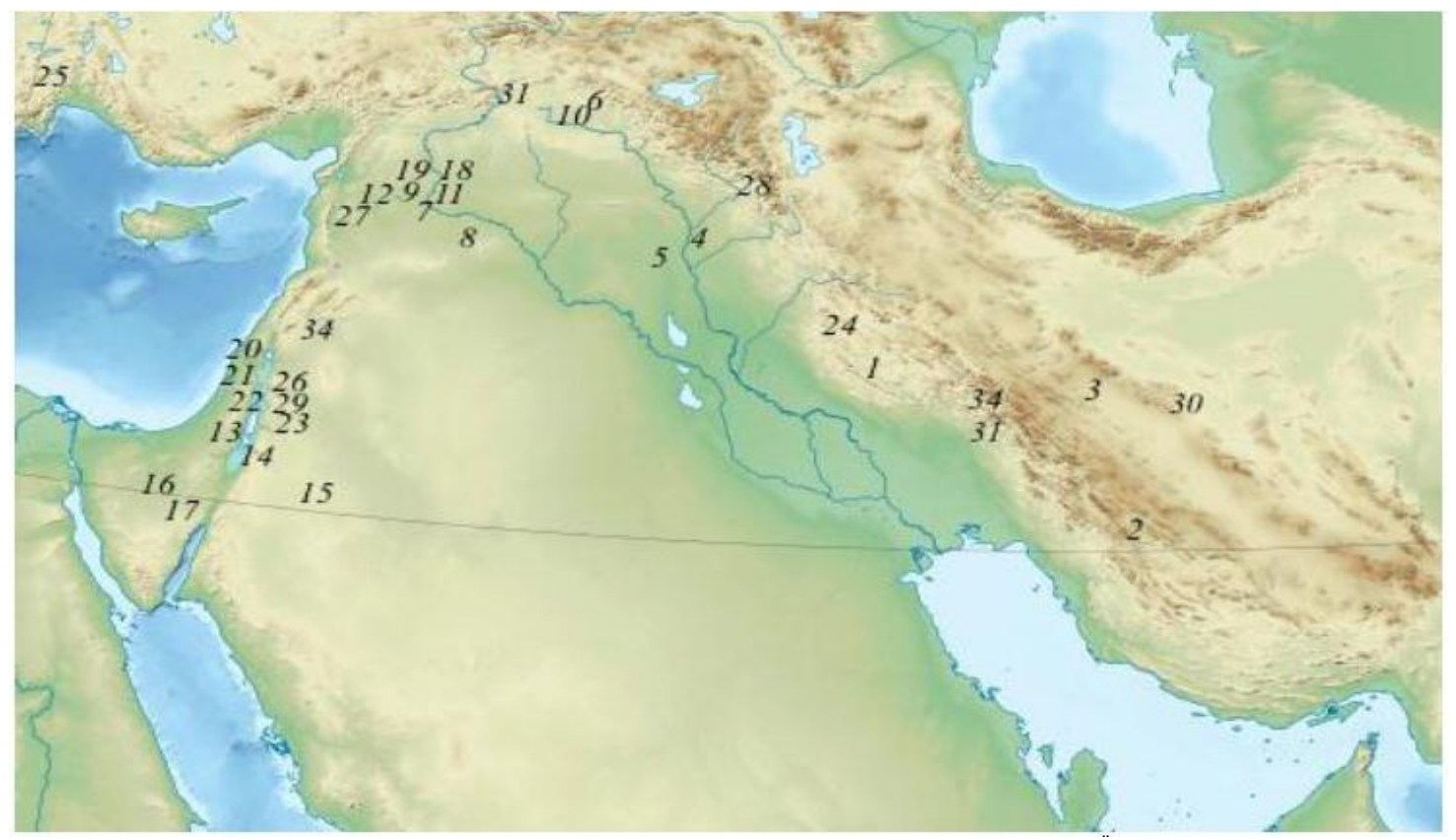

Figure 1. Locations of the sites mentioned in the text
(1) Ghogha Golan
(2) Ghar e Boof
(3) Ganj Dareh Tepe
(4) M'lefaat
(5) Qermez Dere
(6)Hallan Cemi
(7) Mureybet
(8) Abu Hureyra
(9) Djade
(10) Demirköy
(11) Jerf el Ahmar
(12) Qaramel
(13) Gilgal
(14) Dhra
(15) Wadil Jilat
(16) Wadi Feiran
(17) Boker Tachtit
(18) Dja 'de
(19) Tell Abr
(20) Hayonim cave
(21) Kebara
(22) Ohalo II
(23) Wadi al Hammeh
(24) Wezmeh cave

\author{
(25) Öküzini \\ (26) Netiv Hagdud \\ (27) Tell el Kerkh \\ (28) Shanidar III \\ (29) Iraq ed Dubb \\ (30) Tepe Abdul Hosein \\ (31) Ali Kosh \\ (32) Cayonu \\ (33) Tell Aswad \\ (34) Sheikh-e Abad
}


Table 1. Presence or absence of selected taxa common at aceramic Neolithic sites in Southwestern Asia

\begin{tabular}{|c|c|c|c|c|c|c|c|c|c|c|c|c|c|c|c|}
\hline & & 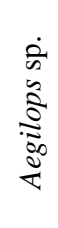 & 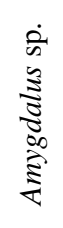 & 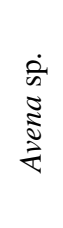 & $\begin{array}{l}\dot{2} \\
\hat{n} \\
\hat{\Xi} \\
\vdots \\
\tilde{\Xi}\end{array}$ & 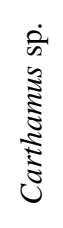 & $\begin{array}{l}\dot{0} \\
\dot{0} \\
\dot{0}\end{array}$ & 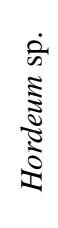 & 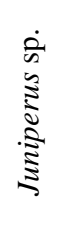 & 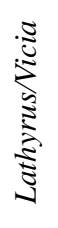 & 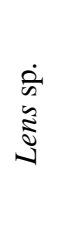 & $\begin{array}{l}\dot{2} \\
\hat{\infty} \\
\hat{\mathbf{5}} \\
\dot{2}\end{array}$ & 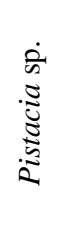 & 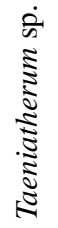 & 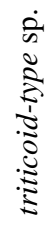 \\
\hline Abu Hureyra 1 & $11150-10450$ & & & $\mathrm{x}$ & $\mathrm{x}$ & & $\mathrm{x}$ & $\mathrm{x}$ & & $\mathrm{x}$ & $\mathrm{x}$ & & $\mathrm{x}$ & & \\
\hline Ali Kosh & $8528-7220$ & $\mathrm{x}$ & & $\mathrm{x}$ & $\mathrm{x}$ & & & $\mathrm{x}$ & & $\mathrm{x}$ & & & $\mathrm{x}$ & & \\
\hline Cayonu & $9442-7000$ & & $\mathrm{x}$ & & & & & $\mathrm{x}$ & & $\mathrm{x}$ & $\mathrm{x}$ & & $\mathrm{x}$ & & \\
\hline Chogha Golan & $12000-9800$ & $\mathrm{x}$ & & & $\mathrm{x}$ & $\mathrm{x}$ & & $\mathrm{x}$ & $\mathrm{x}$ & $\mathrm{x}$ & $\mathrm{x}$ & $\mathrm{x}$ & $\mathrm{x}$ & $\mathrm{x}$ & $\mathrm{x}$ \\
\hline Dhra'2 & $9600-8300$ & & & $\mathrm{x}$ & & $\mathrm{x}$ & & $\mathrm{x}$ & & $\mathrm{x}$ & $\mathrm{x}$ & $\mathrm{x}$ & $\mathrm{x}$ & & \\
\hline Dja 'de & $11000-10300$ & $\mathrm{x}$ & $\mathrm{x}$ & & $\mathrm{x}$ & & $\mathrm{x}$ & $\mathrm{x}$ & & $\mathrm{x}$ & $\mathrm{x}$ & $\mathrm{x}$ & $\mathrm{x}$ & & \\
\hline Ganj Dere Tepe & $9848-8110$ & & $\mathrm{x}$ & & & & & $\mathrm{x}$ & & $\mathrm{x}$ & $\mathrm{x}$ & & $\mathrm{x}$ & & $\mathrm{x}$ \\
\hline Ghar-e Boof & $36030-31000$ & & & & & & & & & $\mathrm{x}$ & & & & & \\
\hline Hallan Cemi & $12000-10900$ & & $\mathrm{x}$ & & & & & & & $\mathrm{x}$ & $\mathrm{x}$ & & $\mathrm{x}$ & & \\
\hline Hayonim cave & $12047-12010$ & & $\mathrm{x}$ & & & & & $\mathrm{x}$ & & & & $\mathrm{x}$ & & & \\
\hline Iraq ed Dubb & $9700-8800$ & $\mathrm{x}$ & $\mathrm{x}$ & & & & & $\mathrm{x}$ & & $\mathrm{x}$ & $\mathrm{x}$ & & $\mathrm{x}$ & & \\
\hline Jerf al Ahmar & $9800-9740$ & & $\mathrm{x}$ & & $\mathrm{x}$ & & & $\mathrm{x}$ & & $\mathrm{x}$ & & & $\mathrm{x}$ & & \\
\hline Kebara & $60000-48000$ & $\mathrm{x}$ & & $\mathrm{x}$ & & $\mathrm{x}$ & $\mathrm{x}$ & $\mathrm{x}$ & & $\mathrm{x}$ & $\mathrm{x}$ & $\mathrm{x}$ & $\mathrm{x}$ & & \\
\hline M'lefaat & $9500-8800$ & $\mathrm{x}$ & & & & & & $\mathrm{x}$ & & $\mathrm{x}$ & $\mathrm{x}$ & & $\mathrm{x}$ & $\mathrm{x}$ & $\mathrm{x}$ \\
\hline Murreybet 2 & $9700-8500$ & & & & $\mathrm{x}$ & & & $\mathrm{x}$ & & $\mathrm{x}$ & $\mathrm{x}$ & $\mathrm{x}$ & $\mathrm{x}$ & & $\mathrm{x}$ \\
\hline Netiv Hagdud & $11300-10900$ & $\mathrm{x}$ & $\mathrm{x}$ & $\mathrm{x}$ & & & & $\mathrm{x}$ & & $\mathrm{x}$ & $\mathrm{x}$ & & $\mathrm{x}$ & & \\
\hline Ohalo II & 19000 & $\mathrm{x}$ & $\mathrm{x}$ & $\mathrm{x}$ & & & & $\mathrm{x}$ & & & $\mathrm{x}$ & & $\mathrm{x}$ & & \\
\hline Qermez dere & $9287-9700$ & $\mathrm{x}$ & & & & & & $\mathrm{x}$ & & $\mathrm{x}$ & $\mathrm{x}$ & & $\mathrm{x}$ & & \\
\hline Sheikh-e Abad & $10100-9140$ & $\mathrm{x}$ & $\mathrm{x}$ & & & & & $\mathrm{x}$ & & $\mathrm{x}$ & $\mathrm{x}$ & $\mathrm{x}$ & $\mathrm{x}$ & $\mathrm{x}$ & \\
\hline Tell 'Abr & $9500-9200$ & & & & & & & $\mathrm{x}$ & & $\mathrm{x}$ & $\mathrm{x}$ & $\mathrm{x}$ & & & \\
\hline Tepe Abdul Hosein & $8450-8655$ & & $\mathrm{x}$ & $\mathrm{x}$ & & & & $\mathrm{x}$ & & & $\mathrm{x}$ & & $\mathrm{x}$ & & \\
\hline Telll Aswad & $9574-8540$ & & $\mathrm{x}$ & & $\mathrm{x}$ & & & $\mathrm{x}$ & & $\mathrm{x}$ & $\mathrm{x}$ & $\mathrm{x}$ & $\mathrm{x}$ & & \\
\hline Wadi Hammeh 27 & $12200-11920$ & $\mathrm{x}$ & & & & & & $\mathrm{x}$ & & & $\mathrm{x}$ & & $\mathrm{x}$ & & \\
\hline Wadi Jilat (6 \& 7) & \pm 11000 & & & $\mathrm{x}$ & $\mathrm{x}$ & $\mathrm{x}$ & & $\mathrm{x}$ & & $\mathrm{x}$ & $\mathrm{x}$ & & $\mathrm{x}$ & & \\
\hline Wezmeh cave & $19000 \& 12000$ & & & & & & & & $\mathrm{x}$ & & & & & & \\
\hline
\end{tabular}

Selected sites mentioned in the text with their radiocarbon dates in calibrated years BP. Kebara is included as a Middle, 
Ghar-e Boof as an Upper and Ohalo II as an Epi- Palaeolithic outlier. Wezmeh cave is a non-anthropogenic late glacial vegetation background of the Central Zagros Mountains.

\section{Methods}

This paper reports only on the charred remains as the desiccated ones may be of a dubious age. The ordination and cluster analyses were made using the statistical programme 'Past' (Hammer et al 2001) and involved the following 12 sites: Abu Hureyra, Cayonu, Ganj dere Tepe, Hallam Çemi, Iraq ed Dubb, Jerf al Ahamr, M'lefaat, Murreybet, Netiv Hagudud, Wadi Hammeh, Wadi Jilat and Chogha Golan horizon XI. The samples from Chogha Golan were floatation and sieving residues from 33 spits from the tell's midden horizon. 23 of these samples were examined by the author; the results are published in the supplementary data for this article, the other eight are published in Riehl et al. 2013.

The ADEMNES database and archaeobotanic reference collection of Tübingen University were used for compiling the analysed datasets. The volumes of sediment and the number of specimens and samples in the studied assemblages were discrepant. For this reason, as the plant diversity broadens in line with the amount of sediment analysed, ubiquity, rather than NISP, was chosen for the analyses (cf. Colledge \& Conelly 2010). Following Colledge's suggestion (2002 p.142) to "look for patterns and trends in data that reflect developmental changes associated with the control and use of plant resources throughout time," correspondence analyses were chosen to "investigate the taxonomic composition" of the assemblages. Using this method the composition of the wild edible taxa and the flora traditionally labeled as weeds from the selected sites were compared. The theoretical background outlined in chapter four discusses the significance of the mode of mobility and residence and the environmental setting inhabited by both plants and humans in examining the assemblage data for signs of cultivation.

\section{Theoretical background}

Literature on the development of agriculture in Southwestern Asia usually states that this process did not occur on its own, but in tandem with a reduction in mobility, more permanent occupation of the landscape and a climatic deterioration connected with the Younger Dryas (Byrd 2005). Whilst the climatic upheaval is evidenced empirically at the regional level in the Levant from speleothems in Soreq cave (Bar-Matthews et al. 1998), and globally in the Greenland ice cores (Severinghaus et al 1998), the two other factors are debated more theoretically.

The task of foraging is disrupted by many factors out of the control of human: For example the cyclical nature of plant life, seasonality, climatic shifts and natural disasters. Thus the plant environment is perpetually in motion; their occupancy in the landscape fluctuates and their composition changes. To overcome the shifting habitat conditions, people must be adaptive. Plants, animals and humans have instinctive, but also develop, strategies to deal with such threats and with varying levels of inter and intra species "competition and population pressure" (Hardesty 1975 p. 73). Humans respond either passively to these changes and pressures (i.e. not affecting other species or its own directly), or actively by modifying their situation, or that of other organisms. An example of 'active' behaviour is the selection of seeds for next year's sowing (Odling-Smee et al. 2003, Laland and O'Brien 2010). As Fuller et al. (2012b p. 625) write: "early foragers focused on increasing the populations of food plants [indirectly] and reducing competition, while yield factors like larger grain, apical dominance, and non-shattering are better understood as unintended consequences selected slowly by some early cultivation practices."

F palaeolithicher examples of active ways to overcome changes in both the human and natural environment are technological innovation, changed subsistence and realigned mobility and residence strategies. Riel-Salvatore (2010 p. 328), for instance discerns alternations between "residential and logistical land-use strategies in response to [the] fluctuating [habitat] conditions." This may equally be called adaptation. Here "residential mobility implies the frequent relocation of base camps in response to depletion of immediately available resources" (ibid.). In this system a pay-off may have existed between the longevity of gathered food sources in an area and their proximity to the residence. "In contrast, logistical mobility implies the more long-term occupation of a base camp provisioned with needed resources through forays at distant points on the landscape targeted at specific resources (ibid.)." In broad terms, the difference between residential and logistical mobility is whether consumers travel to exploit resources (the former), or whether base camps were located in proximity to these resources (the latter). Ghar-e Boof's occupation fits the first pattern: its inhabitants, as traditionally postulated for the Upper Palaeolithic, maintained a broad diet foraged from a range of ecological zones. Chogha Golan's midden occupation can instead be interpreted as transitory, or logistically mobile. Hence the mode of foraging, i.e. subsistence targets and strategies, varied between those sites. Due to the different logistic costs for example, there was a discrepant energy return per foray. Also the abundance and diversity of accessible plants met with whilst roaming would differ.

The ability to store resources is balanced against the satisfaction of the "immediate relative short term needs" of foragers practicing residential mobility with those maintaining logistical mobility (Kaufman 1992 p.172). Sedentism furthers this contrast through the ability to store temporary overproduction of plants and supplement seasonal foraging 
shortages due to the reduced mobility. Following Hayden (1990), I hypothesise that the greater ability to store endurable food in a system of logistical mobility in the Neolithic, compared with the fleeting food supplies of the Palaeolithic, gave rise to a network of hospitality and reciprocity between tell communities. Moreover, changes in systems of residence and mobility fluctuated (cf. Munro 2013) during the Upper and Epi-Palaeolithic and was driven by the era's technological innovations and pressures on the abundance (or not) of food sources. The initial midden occupations of tell sites were at a pivotal point between transitory exploitation with migration between areas, and settling down to a localised subsistence strategy. These frequented loci gradually became focal points in the landscape for camping and social meetings (cf. Hayden 1990). Through these recurring social engagements, the hypothetical system of hospitality and reciprocation could emerge alongside the notion of territoriality. It can be argued that a steadier means of obtaining high value food, than could previously be foraged for, was sought for to maintain the new social interactions, which led to cultivation and gradually to a permanent occupation of the landscape. The tell at Chogha Golan may therefore have developed as succeeding generations of intra-community relationships focussed on the same favourable spot in tandem with more prolonged localised labour efforts to keep up with the needs of cultivation.

In theory, cultivation relies on a minimum of two stimuli that alter the growth of a targeted plant. These in turn also affect the other taxa (plant, animal, insect, fungi, bacteria, etc.) cohabiting its ecology. A key action is modification; either of a particular plant, its community, or its habitat conditions. The activities for example are: pulling out competitors, cutting back old growths to encourage fresh growth, irrigation, shade or light management and turning earth. Once modified, the new environment requires a second stimulus: control, so the modifications do not revert (Jones et al. 1994). If however the process did not begin with an aim in view, or as a mindful experiment, but rather by fluke, then it would be hard to suppose inadvertent maintenance of the plants' new situation. In that case the effort of encouraging or discouraging plant growth for improved yield would have fallen through.

I suggest cultivation is a threefold interdependent engagement. One part acts on factors external to the plant; like management of soil, moisture and light conditions or controlling competitors. A second targets the plants directly, like imposing new germination or growth regimes (Abbo et al. 2013). The third act is to maintain the plants' new situation. When people selected seeds for next year's sowing from mature plants grown under these modified conditions, and exhibiting characteristics preferential to greater yield, it led over prolonged time to morphological and or ecological distinctions compared to the plants' wild ancestors. In some cases it even led to speciation (Fuller et al. 2012a). The amount of time people allocated to modification of the local vegetation and planting depended, according to Barlow (2002), less on yield return from these activities, than on the harvest of higher-return wild resources. If the efficiency of wild plant foraging dropped, due to changing climatic and vegetation conditions then people would have turned to other food sources, or acquired better strategies for obtaining them.

If, however the modifications, brought about by this broadening failed, due to extrinsic factors such as pests or disease, then the energy expended on these efforts was lost without the buffer of wild foraging. Hence it is likely that the earliest stages of this behaviour, expressed for instance by the hunter-forager-cultivators initially frequenting Chogha Golan's midden site, occurred when people were still relatively mobile and able to supplement cultivation with wide foraging forays. Kingwell-Banham and Fuller (2012 p.89) for instance, question whether successful planting certain species "required agricultural intensification and fixed field systems?" Note that most of the species targeted in early cultivation in the archaeobotanic record are plants which provide easily storable food (Zohary 1973) and that the impact of some modifications took longer than one season or one year to appreciate. These then represent, such as in the consumption of fruit and nuts from tended trees, a delayed long-term return on expended effort (Rosenberg et al. 1998, Martinoli 2004, Willcox et al. 2008). This would imply chance to start with.

In sum, no single factor dominates a theoretical background to the development of pre-domestication cultivation, but rather a number of factors are interrelated. A current consensus suggests the change emerged gradually, dependent on regional environmental conditions and local food sources and originating in multiple places (Willcox 2013). Yet underlying the process, in Southwestern Asia, is a concentration of people in the landscape and in their foraging efforts. Arising at the end of the Younger Dryas, but not necessarily directly connected to this climatic fluctuation, a closer look at the environmental conditions in the Zagros Mountains is useful to interpret the developments at Chogha Golan.

\section{Environmental conditions in the Southern and Central Zagros Mountains}

Environmental conditions postulated for intermountain valleys in the Northern and Western Zagros (like Yafteh or Shanidar Cave, cf. Henry 2011) during the Palaeolithic were likely different to those extant in the Dasht-e Rostam or Konjan Cham, because the mountain ranges acted as barriers, which affected the weather and created micro-environments. The complex topography thus limits the use of data from pollen diagrams obtained from lakes further North like Zeribar, Mirabad or Urmia, in interpreting environmental conditions in a more central river valley like the Konjan Cham. Still, as meta-data to the botanic record examined from Ghar-e Boof and Chogha Golan, some wider 
comparison and use of environmental indicators can be pertinent. From the speleothem research in Soreq cave for example we learn that the timing and length of the Younger Dryas can shift dependent on the landscape setting. According to this site $50 \mathrm{~km}$. from the Mediterranean, the Younger Dryas is considered 400 years shorter (from about 13200 to $11400 \mathrm{cal}$. BP) than suggested by the Greenland ice core (Bar-Matthews et al. 1998 and Severinghaus et al 1998). As such palaeo-climatic data is lacking from the Ilam province, it is possible that the YD occurred there later than further West in the Fertile Crescent. Alternatively, this late-glacial stage did not affect the early occupation of Chogha Golan as much as suggested at other sites like for example Abu Hureyra (Hillman et al. 2001). Indeed the significance of the YD in the emergence of pre-domestication cultivation, and its role in the vegetation changes - like the decline of the steppe species (e.g. Chenopodiaceae and Artemisia) and the gradual establishment of open woodland plant communities - is debated. Colledge and Conelly (2010) for example, criticise Hillman's et al. 2001 interpretation of the environmental conditions along the Euphrates and the influence this had on the development of cultivation. According to them, the "changes in the proportions of plant taxa between the earlier and later phases at Abu Hureyra" are neither due to an altering climate, or agricultural practices (Colledge 2010 p. 125). For a comparable zooarchaeological conclusion that doubts the "causal role of the YD in the adoption of agricultural economies," see Munro 2003. In her analysis of small game hunting in the Southern Levant, she does not see the YD as causing food stress, or that this led to a change in subsistence strategies.

In brief, Ghar-e Boof was occupied during the onset of the glacial interstadial 8 in MIS 3. According to oxygen isotopes, and the lower cores from lake Zeribar, the climate was likely to have been mild and moist, or a less colder stage during the glacial period (Wasylikowa 2005). At the beginning of Chogha Golan, aridity was high, yet decreasing and the mean temperature was climbing. This means the habitats of wild grasses, pulses and fruit plants foraged for were spreading. With the reestablishment of tree cover and diverse, yet lower-yield, plants, it is unfounded to speak of a contraction of exploitable plant and animal food sources in the landscape around the tell. For the Central Zagros (cf. lake Hula for the Western Levant; Stevens et al. 2001), environmental and climatic conditions were unlikely therefore to cause a large drive to cultivation of high-yield plants as a supplement to poor foraging returns (Bottema 2002 p. 37). The social conditions developing around widening networks of production at favourable and frequented loci in the landscape, like tells, perhaps ask for renewed interest (Hole 1978).

\section{Results}

\subsection{Legume foraging tradition}

Recovery of Cicer sp., Lathyrus sp., Pisum sp. and Vicia sp. at Ohalo II and Kebara cave suggests pulses were collected in the Epi- and Middle Palaeolithic respectively (Albert 2000, Weiss 2004). People continued foraging for them throughout the succeeding millennia, though "in the absence of substantial storage" ability and yield enhancement, they would have provided less "post-encounter nutritional returns than big game" (Stutz et al. 2009 p. 9). The tradition persisted throughout the Upper Palaeolithic at sites like for instance Ghar e Boof or Hayonim Cave (Hopf 1987).

Natufian stone tool use-wear analysis by Dubreuil (2004) also indicates an increased use of flat grinding stones or querns for breaking legume and cereal seeds into meal in the Western Levant. By the Neolithic, practices were developing, perhaps leaning in part on a long legume foraging heritage, to obtain higher yields and a storable seasonal surplus. For legumes, as with cereals, temporary residence opened the way to increased exploitation and storage capacity, when compared to the small caches of nomads. According to Abbo et al. (2008) sedentarism also played a role in making possible the discovery and application of seed manipulations like scarification and new germination regimes, that led over time to domestication of some selected species. Contrary to a protracted development of pre-domestication cultivation suggested by Fuller and other scholars, Abbo and Albert disagree on the time-span involved between the first planting attempts and domestication (Abbo 2013, Albert 2000 and Fuller et al. 2012b). They believe this development occurred quickly and in sedentary communities, rather than during a long process of practice and innovation passed down through millennia by mobile hunter-gatherers. However, Abbo does not refute the significance of a longstanding custom of legume foraging in the process of developing their cultivation and later domestication (Abbo 2013). Nor that these efforts were always successful or exclusive to a core area. Some trials were abandoned for instance, like the attempts with Vicia peregeina, cultivated between 11300 - 10900 years ago alongside Hordeum sp., at Netiv Hagdud in Southern Jordan (Melamed 2008). Many were successful and still common today, like the domestication of Cicer arietinum at Tell el-Kerkh during the late $10^{\text {th }}$ Millennium BP in Northwestern Syria were (Tanno \& Willcox 2006). Note that though chickpeas were also found in the Middle Palaeolithic horizons of Kebara cave, they do not occur at the other PPNA sites examined in this paper (see table 1 and figure 2). 


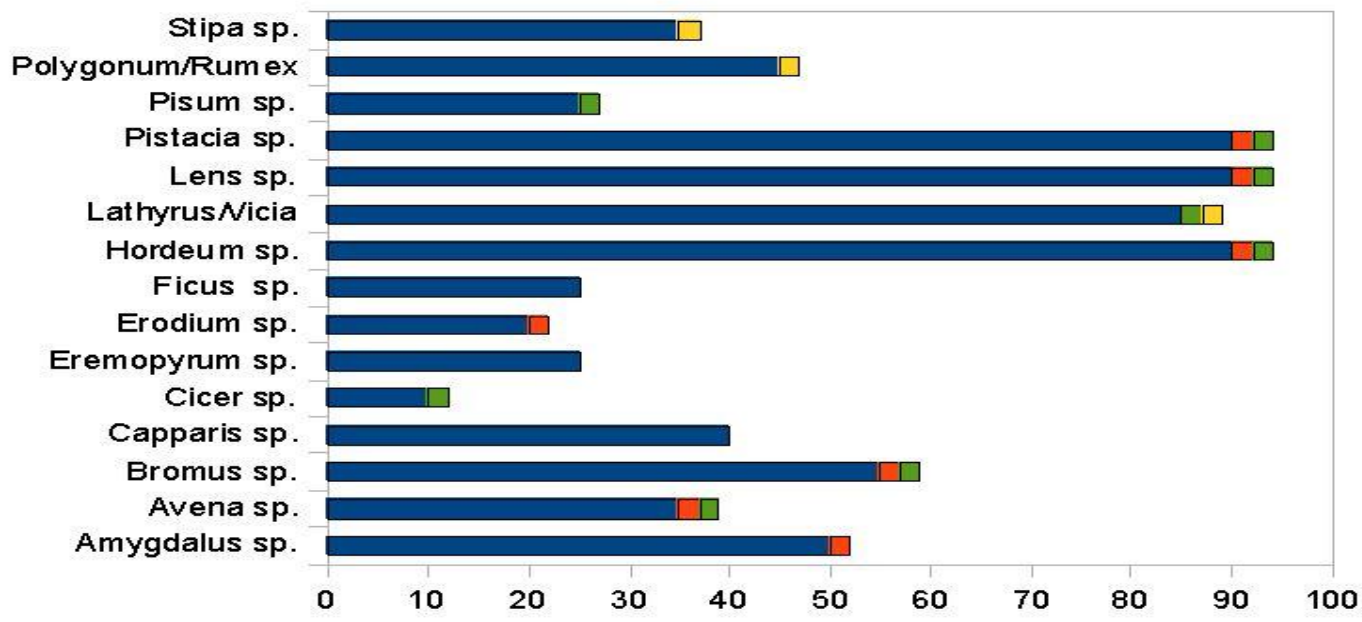

Figure 2. The ubiquity of selected edible taxa by percentage of presence at the aceramic Neolithic sites of table 1 in blue with the three outliers: Ohalo II in orange, Ghar-e Boof in yellow and Kebara in green

Proponents of early pulse cultivation question however the efficiency of wild collection at a time when residential mobility was declining (cf. the Kebaran-Natufian transition in Jordan Diaz et al. 2012). The sparse coverage of legumes in the landscape meant sowing them nearby the settlement, and/or tending wild patches in its wider vicinity, would reduce the otherwise high logistic cost and small energy return of just foraging for them nomadically. Balancing or improving the cost-benefit ratios of foraging were therefore central concerns in the development of legume cultivation. The Fabaceae recovered from sites in our study area are therefore divided into two categories depending on the energy expenditure and return from collecting them (Zohary 2012 and Edwards ed al. 2004). Those plants returning a low amount of energy or a small volume per unit of time were likely avoided, but may have entered the analysed assemblages inadvertently when targeted plants were collected. The presence of some of these smaller seeds and fruit is conditionally indicative of cultivation as weed flora; mainly of Poaceae but also Fabaceae (Garrard et al. 1988, Savard et al. 2003). Our modernity clouds this categorisation however. Known useful small seeded plants like Brome grass (Bromus sp.) Lupine (Lupinus sp.) and mustard (Brassica sp.) are recognised as foraged at Ohalo II (Diaz et al. 2012). Yet other small seed and fruit, the possible consumption or uses of which are nowadays unknown, are not considered as exploited. The vast array of Astragalus, Medicago, Melilotus, Scorpiurus, Trifolium, Trigonella, among other Fabaceae, are thus not considered targets of cultivation (Abbo et al. 2008). Other uses are for example the laying down of Fabaceae, and Cyperaceae, as bedding material as is evident at Ohalo II and Abu Hureyra (Hillman et al. 2001, Nadel et al. 2004). Foraging Fabaceae was a seasonal supplement in a broad diet package, rather than a staple resource, because of the high travelling and preparation cost expended (Abbo et al. 2008, Ladizinsky 1987, Weiss et al. 2004). But later, when people began cultivating pulses, these expenditures dropped below the gains and they became more attractive food sources. Note that not all the legumes discussed are climbing plants needing care in order to obtain serious yields: the carob seed (Ceratonia siliqua) found in the Sinai at Wadi Feiran and Boker Tachtit drop plentifully from a sturdy bush (Phillips 1988).

\subsection{Fruits and nut trees}

Identification of juniper (Juniperus sp.) and (Morus nigra) pips at Chogha Golan is neither exceptional - they are evident at Öküzini, Gilgal 1 and other Levantine Epi-Palaeolithic and PPN sites (see figure 2) - nor straightforward evidence of manipulation of their parent trees (Bar-Yosef et al. 1977, Kislev et al. 2006 and Noy 1989). That junipers grew in the Zagros Mountains during the late glacial era finds support in pollen remains from hyena coprolites from Wezmeh cave dating to 19000 and 12000 cal. BP (Djamali 2011). Juniper however was not identified at the other sites in table 1. Note other usages of arboreal fruit were possible as must be the case for the conspicuous identification of poisonous Rhamnus palaestinus seed at numerous sites in the region like Wadi al Hammeh 26, Kebara cave and Abu hureyra (Bar-Yosef et al. 1977). Nevertheless, even the numerous pistachios (Pistacia sp.) and almonds (Amygdalus sp.) recovered are not proof that people planted, pruned or gave particular care to fruit and nut bearing trees in order to obtain larger yields (Willcox et al. 2009). Remark how almond joins on the edge of the cluster plot in figure 3 with weeds typical of early cereal cultivation, yet it is distant from the wild grasses common to cereals' habitat. If cultivation was practised, then almonds lie contrastingly with those plants understood as discarded. Supposing it was only in its infancy alongside a hunting and gathering subsistence, then these weeds came with the foraged seeds, fruits and nuts that grow near each other. 


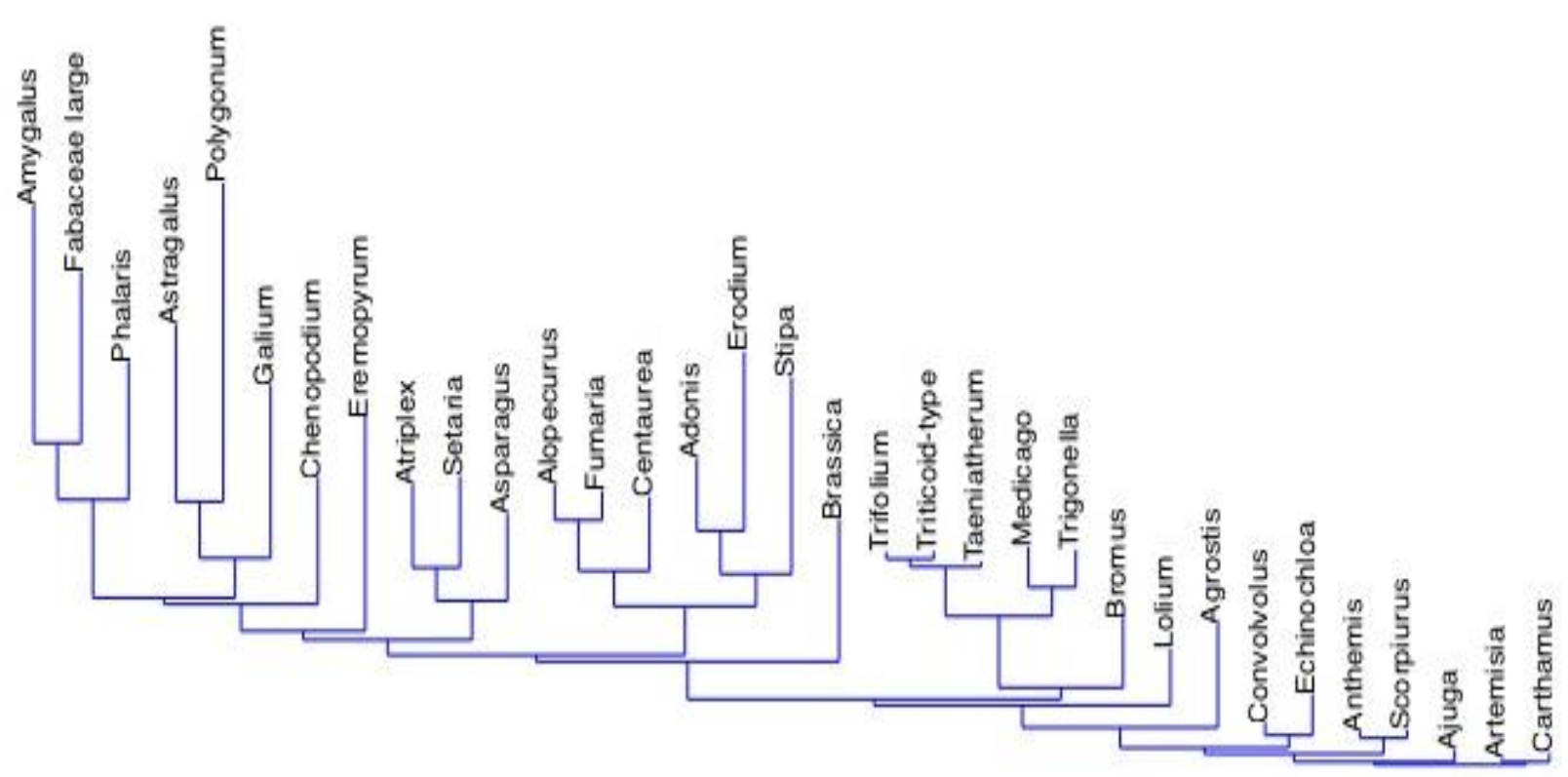

Figure 3. Cluster plot of the ubiquity of weeds and medium seeded grasses in the assemblages of the 12 chosen sites with almond as an outlier.

\subsection{Tending and planting cereals}

A central way discussed in the literature to distinguish between seeds that were the produce of cultivation, and those of foraging wild stands, is to analyse the presence of weeds (Colledge 2004). Weeds may in this case be considered as niche companions of cultivated plants. They could benefit from modifications aimed at improving the yield of the tended plants. They may even have been removed from cultivation plots as unwanted, but in the absence of firm evidence this is speculation. Though many taxa share, for example barley's (Hordeum sp.) habitat, a few particular genera of weeds stand out proportionally and are ubiquitous compared to the other plants in the analysed assemblages (Savard et al. 2006). Even under stress of changing climate, cereals and weeds conspicuously persevere. Fuller suggests that they "persisted in a new habitat (Fuller 2007 p.907)." Thus a side-effect of cereal cultivation was that weeds also benefited from an increased resilience to adverse conditions in the environment that was constructed to further the target plants. Table 2 and figures 4 and 5 suggests horizon XI of Chogha Golan had a particular weed component (cf. Colledge et al. 2004, Willcox 2009). This could signal that barley was cultivated near the tell, and that some of its wild habitat companions (i.e. weeds) grew and were harvested along with the cereal. 
Table 2. The presence or absence of arable weed taxa

\begin{tabular}{|c|c|c|c|c|c|c|c|c|c|c|c|c|c|c|}
\hline & 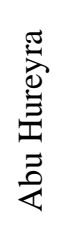 & 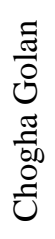 & $\begin{array}{l}\stackrel{\theta}{0} \\
\stackrel{\sigma}{0} \\
\stackrel{\sigma}{0}\end{array}$ & 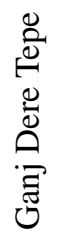 & 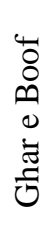 & 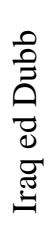 & 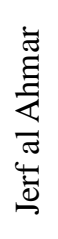 & 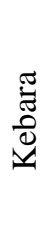 & 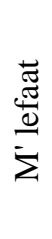 & 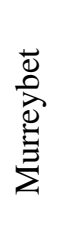 & 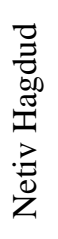 & 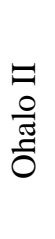 & 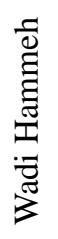 & 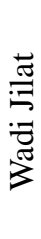 \\
\hline Adonis sp. & & $\mathrm{x}$ & $\mathrm{x}$ & & & & $\mathrm{x}$ & & $\mathrm{x}$ & $\mathrm{x}$ & $\mathrm{x}$ & & & $\mathrm{x}$ \\
\hline Arnebia sp. & $\mathrm{x}$ & & $\mathrm{x}$ & & $\mathrm{x}$ & & & & & $\mathrm{x}$ & $\mathrm{x}$ & & & $\mathrm{x}$ \\
\hline Astragalus sp. & & $\mathrm{x}$ & & $\mathrm{x}$ & $\mathrm{x}$ & & & $\mathrm{x}$ & $\mathrm{x}$ & $\mathrm{x}$ & $\mathrm{x}$ & & & \\
\hline Bellevalia sp. & $\mathrm{x}$ & $\mathrm{x}$ & & & & & & $\mathrm{x}$ & $\mathrm{x}$ & $\mathrm{x}$ & $\mathrm{x}$ & & & \\
\hline Bromus sp. & $\mathrm{x}$ & $\mathrm{x}$ & $\mathrm{x}$ & $\mathrm{x}$ & & $\mathrm{x}$ & $\mathrm{x}$ & $\mathrm{x}$ & & $\mathrm{x}$ & & $\mathrm{x}$ & $\mathrm{x}$ & $\mathrm{x}$ \\
\hline Centaurea sp. & & $\mathrm{x}$ & $\mathrm{x}$ & & $\mathrm{x}$ & & $\mathrm{x}$ & & $\mathrm{x}$ & $\mathrm{x}$ & $\mathrm{x}$ & & & $\mathrm{x}$ \\
\hline Chenopodium sp. & $\mathrm{x}$ & $\mathrm{x}$ & $\mathrm{x}$ & $\mathrm{x}$ & $\mathrm{x}$ & $\mathrm{x}$ & $\mathrm{x}$ & $\mathrm{x}$ & $\mathrm{x}$ & $\mathrm{x}$ & $\mathrm{x}$ & $\mathrm{x}$ & $\mathrm{x}$ & $\mathrm{x}$ \\
\hline Fumaria sp. & & $\mathrm{x}$ & $\mathrm{x}$ & $\mathrm{x}$ & & & & & & $\mathrm{x}$ & $\mathrm{x}$ & & & $\mathrm{x}$ \\
\hline Galium sp. & & $\mathrm{x}$ & $\mathrm{x}$ & $\mathrm{x}$ & $\mathrm{x}$ & $\mathrm{x}$ & $\mathrm{x}$ & $\mathrm{x}$ & & $\mathrm{x}$ & & $\mathrm{x}$ & & \\
\hline Glaucium sp. & $\mathrm{x}$ & $\mathrm{x}$ & $\mathrm{x}$ & $\mathrm{x}$ & $\mathrm{x}$ & $\mathrm{x}$ & $\mathrm{x}$ & & & & & $\mathrm{x}$ & & \\
\hline Heliotropium sp. & $\mathrm{x}$ & $\mathrm{x}$ & $\mathrm{x}$ & $\mathrm{x}$ & $\mathrm{x}$ & & & & $\mathrm{x}$ & $\mathrm{x}$ & $\mathrm{x}$ & & & $\mathrm{x}$ \\
\hline Lepidium sp. & $\mathrm{x}$ & $\mathrm{x}$ & & & $\mathrm{x}$ & & & & & & & & & \\
\hline Lolium sp. & $\mathrm{x}$ & $\mathrm{x}$ & & & $\mathrm{x}$ & & $\mathrm{x}$ & & & & & & $\mathrm{x}$ & $\mathrm{x}$ \\
\hline Papaver sp. & $\mathrm{x}$ & $\mathrm{x}$ & $\mathrm{x}$ & & $\mathrm{x}$ & & & & & & & & & $\mathrm{x}$ \\
\hline Polygonum sp. & $\mathrm{x}$ & $\mathrm{x}$ & $\mathrm{x}$ & & $\mathrm{x}$ & & $\mathrm{x}$ & & $\mathrm{x}$ & $\mathrm{x}$ & & & & \\
\hline Setaria sp. & $\mathrm{x}$ & & & & $\mathrm{x}$ & & $\mathrm{x}$ & & & $\mathrm{x}$ & & $\mathrm{x}$ & & \\
\hline Silene sp. & & $\mathrm{x}$ & $\mathrm{x}$ & $\mathrm{x}$ & $\mathrm{x}$ & & $\mathrm{x}$ & & & $\mathrm{x}$ & $\mathrm{x}$ & & & \\
\hline Spergula sp. & $\mathrm{X}$ & $\mathrm{x}$ & & & & & & & & & & & & \\
\hline
\end{tabular}

The sites in table 2 are broadly contemporary to Chogha. Ohalo II, Ghar e Boof and Kebara are included as Epi-, Upper and Middle Palaeolithic outliers. 


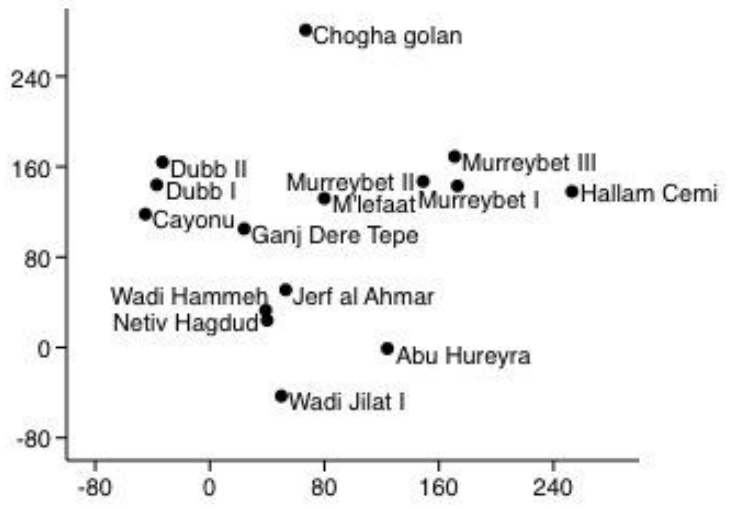

Figure 4. Ordination plot of the ubiquity of the weed taxa in the assemblages of sites contemporary to Chogha Golan and other aceramic Neolithic sites in Southwestern Asia.

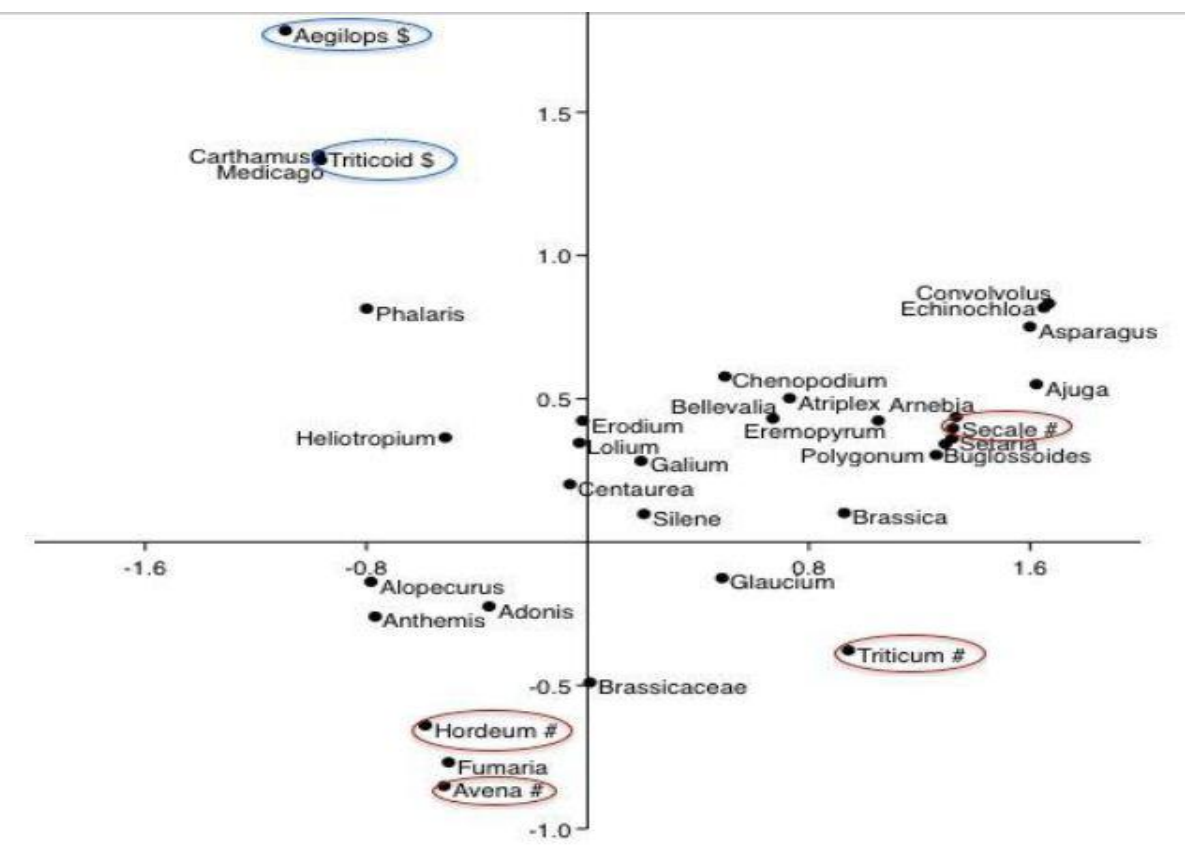

Figure 5. Correspondence analysis of the ubiquity of recorded weeds and cereals in the assemblages from the 12 chosen sites. \# sign marks traditional cereals and \$ marks those grasses that were possibly eaten.

In a reassessment of Abu Hureyra's assemblage, Colledge and Conolly (2010) suggest a widening of foraging activities to include "lower-ranked" foods, rather than cultivation as was suggested by Hillman (2001). Indeed identifying a weed component in a horizon need not be interpreted as modification of a plant's wild growing conditions to the extent of cultivation, as these plants share the same ecology with cultivated species in the wild. In figure 6 , which plots all the edible, useful and weed taxa found in Chogha Golan's lowest horizon, the larger edible grasses, legumes and nuts cluster on the lower right quarter of the graph, yet in proximity to a few companions of their wild habitat. However, some of the other edible seeds and fruits, but also weeds, scatter arbitrarily across the rest of the plot. This corresponds to gathering of the wider spectrum of edible regional vegetation; including a number of cohabiting non-useful plants, inadvertently harvested with the targeted species. Because such foraging did not affect the plants directly in the sense of changed seed morphology or plant physiology, no distinguishing characteristics between targeted and randomly gathered seed and fruit were found. Therefore I suggest that shifts in subsistence procurement took place, rather than cultivation per se, following hunter-gatherer responses and actions inherited from when people came under stress due to 
their demography or behaviour or changes in their environment (cf. resilience theory followed by Rosen 2012).

Signs for associations between taxa that are edible and share the same ecology, such as Taeniatherum sp. and Eremopyrum sp., (cf. Fairbairn et al. 2007) and the typical crop or functional plants, were looked into as well. Though some edible species cluster near one another, as do some cultivated plants, they are rather scattered and associate rather more closely to those taxa that share their preferred environmental conditions. I hypothesise this indicates targeting plants of specific worth, over less energetically economic or useful ones. Exceptions in the plots are noticeable however, as is the case with Capparis sp. (cf. Garrard 1988 and Willcox 1996) and Amygdalus sp. which might indicate that these plants are site-context specific (see figure 2 and 6). The analyses nonetheless suggest more close correspondence ecologically between plants than any groupings derived from removing targeted plants from their wild companions in the local environment. This would agree with predictions from behavioural ecological models that hunter-gathers primarily foraged for high yield food, over less rich plants (Broughton et al. 2010, Colledge 2010). Yet as plants with preferential traits to the occupants of tell sites, they do not stand out from the other plants that share their ecology in the wild. Thus the analyses sway me more towards broad foraging in the landscape, rather than adjusting plants to people's new needs or situation through cultivation.

Eating wild cereals in the Middle Palaeolithic finds support in the identification of ripe grass panicles at Amud Cave, intentionally brought on site by its Neanderthal inhabitants (Madella 2002 p.714). Hordeum sp. starch moreover, trapped in the dental calculus of a Neanderthal, was found at Shanidar III in Iraq (Henry 2011). Note that starch grains of dates (Phoenix sp.), water lilies (Nymphaeae sp. and Nuphar sp.), legumes and a relative of sorghum were also identified in the same study from Spy cave in Belgium (ibid.). Wild cereal seeds retrieved from samples dating to 19 $000 \mathrm{BP}$ from Ohalo were similarly interpreted as foraged, in the absence of a distinct weed complex (Kislev 1992).

The assemblages were also analysed for indicators (such as Ajuga sp. and Galium sp.) that cereals were cut low by the base, or uprooted (Kislev et al. 2004). This could in part have explained the weed component's strength, but the datasets lacked clear signs. Identifications to the species level within the same genus in the dataset were also investigated for clustering or correspondences (see figure 7). Whilst plots of the number of specimens revealed nothing conclusive, plots of species ubiquity shows how the edible Vicia / Lathyrus cluster with Vicia ervilia, but are only distantly joined to Vicia faba and the undefined Vicia sp. As no other associations are obvious, we conclude that the loss of detail by working with datasets of identification only down to the genus level remains acceptable.

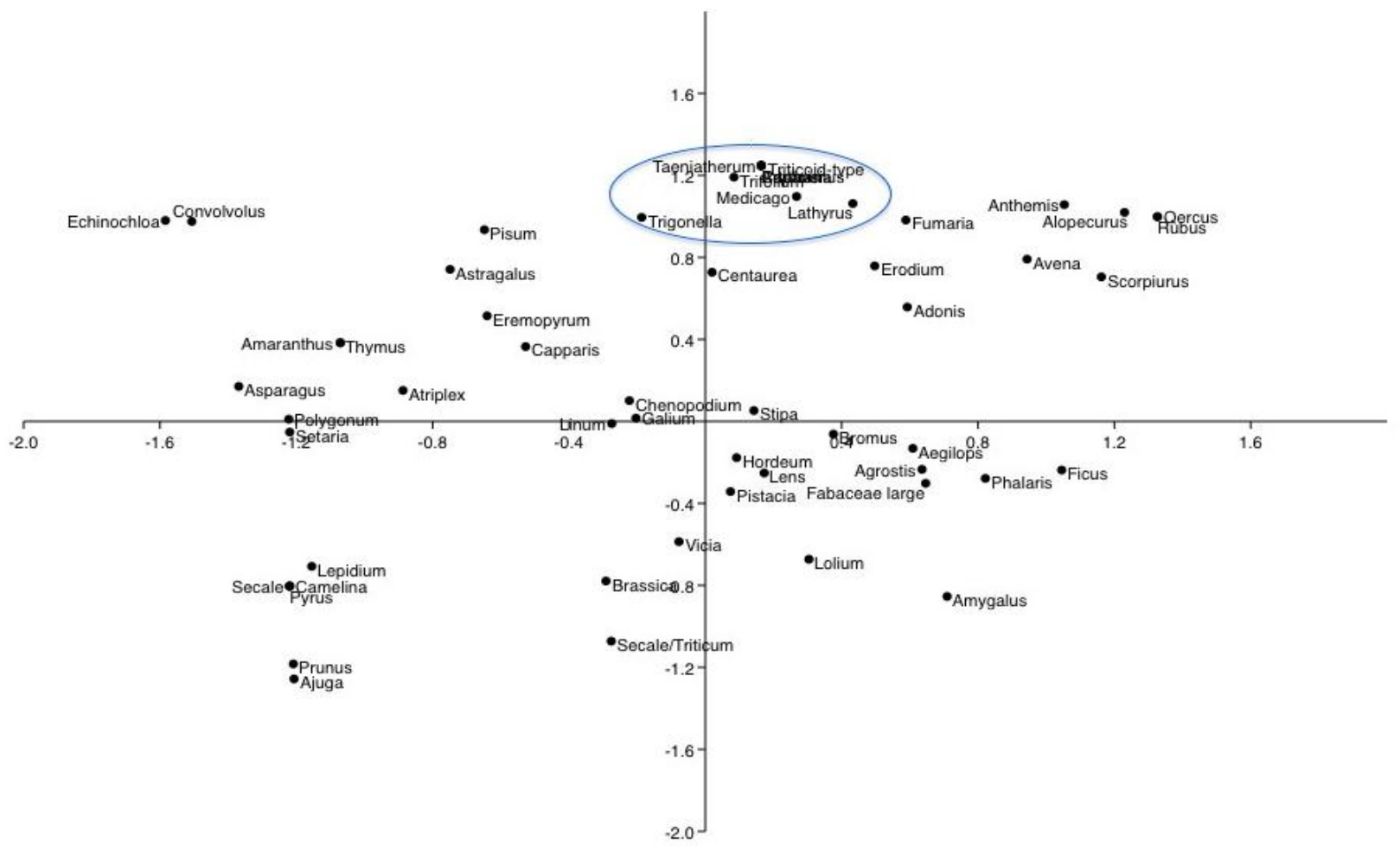

Figure 6. Correspondence analysis of the ubiquity of recorded edible, useful and weed taxa from horizon XI at Chogha

Golan's. Note moreover that the triticoid-types lie in a recurring constellation of taxa (Taeniatherum, Trifolium and

Carthamus) as in figures 3 and 5. 


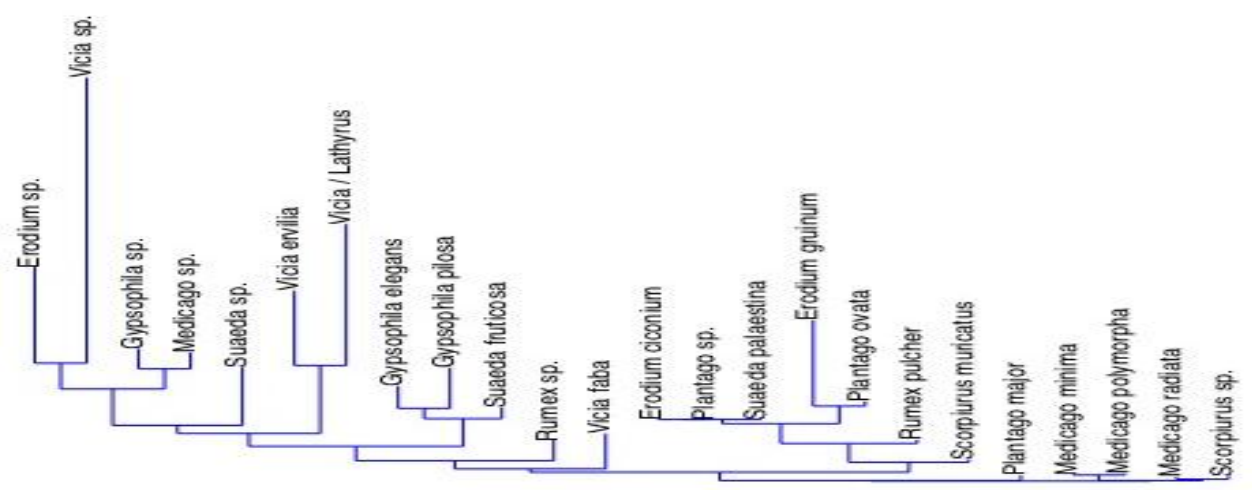

Figure 7. Cluster plot of the ubiquity of selected grasses, herbs and legumes from Chogha Golan's first horizon to examine how closely statistically associated are related plants that were identified to the genus and species level.

Over prolonged association in the arable field and due to the effects of cultivation, hybridization can occur between weeds and cultivated plants. A typical example can be shown with the appearance of free threshing wheat (Triticum aestivum) and will be briefly discussed before turning to other steppe and meadow plants. Although goatgrasses (Aegilops sp.) were abundant at Chogha Golan, the agent behind the emergence of free threshing wheat: emmer (Triticum dicoccum), which was later found, Triticum aestivum has not been found. Nor were any Aegilops tauschii specimens, the source goatgrass of the hybridization, identified. As both parent plants were native to the region, we presume that free threshing wheat's full hybridization occurred after the site's use ended. Moreover, as goatgrasses were equally comestible as wild emmer, it is unlikely that their high specimen count in the earliest tell horizon was due to purposeful burning as rubbish. Rather, it makes sense to conclude that the foraging efforts during this horizon did not exclude goatgrasses. Whilst Triticum boeoticum/dicoccoides became more numerous in later horizons, the proportion of Aegilops dropped. I see this, with slim corroboration from other sites (see table 3 charting Aegilops sp. and selected small-seeded grasses and legumes and figure 5 (cf. Hillman 2001; Savard et al. 2006 and Willcox et al. 2009), as an indication that people, upon adoption of cultivation practices, began better sorting through their seed stock for sowing and removing of weeds to keep them out of cultivated plots.

Table 3. Presence of small-seeded grasses, legumes and herbs

\begin{tabular}{|c|c|c|c|c|c|c|c|c|c|c|}
\hline & $\begin{array}{l}\overrightarrow{0} \\
\stackrel{\Xi}{2} \\
\text { Abu I }\end{array}$ & $\begin{array}{c}\mathcal{N} \\
\tilde{J} \\
\stackrel{\Xi}{2} \\
\text { ureyra }\end{array}$ & $\begin{array}{l}\bar{x} \\
\tilde{0} \\
. \overline{0} \\
0\end{array}$ & 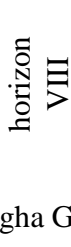 & 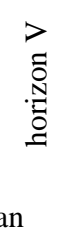 & 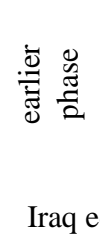 & 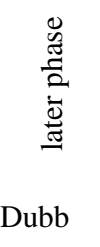 & 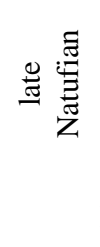 & 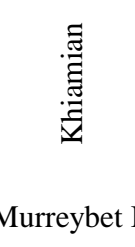 & $\underset{z}{\mathbb{Z}}$ \\
\hline & 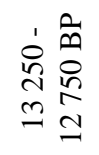 & $\begin{array}{l}1 \\
8 \\
8 \\
8 \\
0 \\
0 \\
0\end{array}$ & $\begin{array}{l}\text { ติ } \\
8 \\
\varnothing \\
=\end{array}$ & $\begin{array}{l}\stackrel{0}{\infty} \\
8 \\
\stackrel{0}{0}\end{array}$ & $\begin{array}{l}0 \\
\text { ต } \\
8 \\
0 \\
0\end{array}$ & 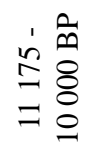 & $\begin{array}{l}1 \\
\delta \\
\delta \\
\delta \\
o \\
0 \\
0 \\
0 \\
\sigma\end{array}$ & 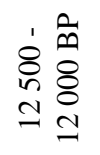 & 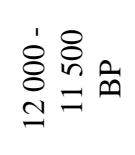 & 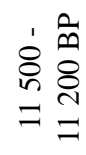 \\
\hline Aegilops sp. & 0 & 0 & $\mathrm{x}$ & - & - & $\mathrm{x}$ & - & 0 & 0 & 0 \\
\hline $\begin{array}{l}\text { Astragalus sp. } \\
\text { Trigonella sp. }\end{array}$ & $\mathrm{x}$ & + & $\mathrm{x}$ & - & - & 0 & 0 & $\mathrm{x}$ & - & - \\
\hline Chenopodium sp. & $\mathrm{x}$ & + & $\mathrm{x}$ & - & - & $\mathrm{x}$ & - & $\mathrm{x}$ & - & - \\
\hline Eremopyrum sp. & $\mathrm{x}$ & + & 0 & 0 & 0 & 0 & 0 & $\mathrm{x}$ & - & - \\
\hline $\begin{array}{l}\text { Medicago sp. } \\
\text { Trifolium sp. }\end{array}$ & $\mathrm{x}$ & + & $\mathrm{x}$ & - & + & $?$ & $?$ & $\mathrm{x}$ & - & - \\
\hline Phalaris sp. & 0 & 0 & $\mathrm{x}$ & - & + & $\mathrm{x}$ & - & 0 & 0 & 0 \\
\hline Polygonum sp. & $\mathrm{x}$ & - & $\mathrm{x}$ & $?$ & $?$ & $\mathrm{x}$ & $?$ & 0 & $\mathrm{x}$ & + \\
\hline Scirpus sp. & $\mathrm{x}$ & + & $\mathrm{x}$ & - & - & 0 & 0 & $\mathrm{x}$ & + & $\mathrm{x}$ \\
\hline Setaria sp. & $\mathrm{x}$ & - & 0 & 0 & 0 & $?$ & $?$ & $\mathrm{x}$ & - & - \\
\hline Stipa sp. & $\mathrm{x}$ & + & $\mathrm{x}$ & ? & + & 0 & 0 & 0 & 0 & 0 \\
\hline
\end{tabular}


Table 3 compares the record of some small seeded grasses, legumes and herbs between Chogha Golan, divided into an early, middle and late occupation phase, and the main occupation phases of three other roughly contemporaneous sites in Southwestern Asia. x means a presence, 0 means an absence, ? means data unknown, - represents a proportional decrease and + represents a proportional increase compared to the previous period.

It would be wrong to impress on the reader a view that cultivated food species never disappeared, and that only those plants known today as crops were cultivated in the past. Archaeobotanical evidence for instance "indicates a number of lost crops, which were cultivated and even morphologically domesticated, but are no longer extant" (Fuller et al. 2012b p. 629). We examined whether the triticoid-types from Chogha Golan also fit this scenario. When plotted amongst weeds and cereals, they lie away from the latter, but correspond closely to some weeds (see figures 5). Plotted amongst edible and useful plants and weeds, they again ordinate near weeds (see figure 6). Plotted by number of specimens, rather than by ubiquity as in the previous two analyses, again triticoid-type does not ordinate with true crop plants. Note however, that they were found in low amounts at just three other sites: Ganj Dere Tepe, Murreybet and M'Lefaat (Savard et al. 2003). They are specimens that have no known modern comparative in the Zagros Mountains, but occur at various prehistoric sites in the region like Ganj Dareh Tepe and the Northeastern Syrian Khabur (see photograph 1). Their typology follows van Zeist's (1984 \& 2001) descriptions and lean towards Hordeum sp., Secale sp. or Triticum sp., but do not fit either of these genera conclusively, so the label triticoid-type is most correct. Either they are grains from plants not yet found in the wild, or that have gone extinct. Or more plausibly, like the two grained form of einkorn ( $T$. Urartu), they are traces of an abandoned early cultivated lineage of a grass in the triticae tribe (Fuller et al. $2012 \mathrm{~b}$. 620).

Photograph 1. three triticoid-type grains from Chogha Golan horizon XI, Iran

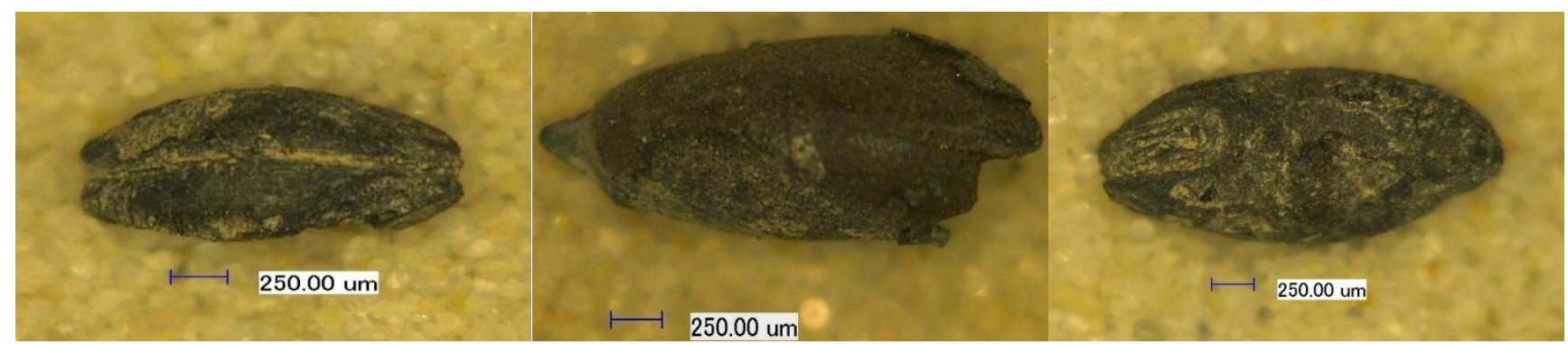

6. 4 Wild plants from the arable field

Another group of plants grew among the wild cereals and in cultivation plots that are not considered weeds. Like Aegilops sp., they either entered the site assemblage inadvertently during collection of targeted species, or on purpose as food. In the Middle Palaeolithic levels of Kebara Cave for example, bromegrass (Bromus sp.) and safflower (Carthamus sp.) were found (Lev 2005). In the archaeobotanical record of sites dating to the following tens of millennia, the list of small seeded grasses and legumes and genera in the dock (Polygonaceae), sedge (Cyperaceae) and beech (Fagaceae) families, found in contexts with the aforementioned food plants, increase and diversify (Hopf 1987; Kislev 1988; Savard 2006 and Willcox et al.2008). That they remained an integral part of the wild plant use of early farmers is attested to by Fairbairn et al.'s (2007) research of assemblages dating between 6200 and 6600 cal. BC from Çatal Höyük and Savard et al.'s (2003) studies at M'lefaat from around 9900 uncal. BC. By the PPN, the range of wild plants identified as possible seed, leaf and nutlet additions to the diet of hunter-gatherers clouds a strict definition of which plants were chosen in early cultivation attempts. Because cereals or pulses do not occur alone in wild stands, but together with these other plants, when people modified their wild ecology, it affected their habitat companions as well.

I hypothesise that as people began cultivation proper, that is in a way noticeable in the archaeobotanic record, which is suspected at Chogha Golan in the horizons succeeding its initial one, then the volume of specifically targeted species should increase, whilst the number of smaller edible taxa, but not weeds, would decrease. The analyses by Weiss et al. at other sites suggest such a trend, and they describe it as a shift in the hunter-gatherer broad spectrum diet. They saw for instance in the assemblages from Ohalo II, and 19 other selected sites in the Levant, a gradual decline in the small seeded grasses between the Epipalaeolithic and the PPNB (Weiss et al. 2004 and a similar study cf. Colledge et al. 2004). However, a hypothesised trend for a region is not a given for each site. Environmental conditions, residence context and the availability and diversity of food sources dictated the opportunistic hunting-gathering-cultivating strategies at each locality. Hence exceptions like: M'lefaat, Qermez Dere, Abu Hureyra, Çatal Höyük, Zharat adh-Dhra' 2 and Iarq ed-Dubb, where subsistence was diverse and not based primarily on large seeded grasses, are reported (cf. Savard et al. 2006 and Edwards et al. 2004). The number and diversity in these smaller edible legumes and grasses remains similar, or even increases, during Chogha Golan's occupation (see table 3 and Riehl et al. 2013 supplement). I 
surmise that the people, who initially visited the site and raised the midden, foraged wild plant food mainly, yet also experimented with cultivation.

\section{Conclusions}

One can speak of the development of agriculture at the end of the Palaeolithic as a realignment of hunter-gatherer traditions to a transforming human and natural setting. Increased foraging efficiency and stability were sought, as were the adoption of new residence and mobility strategies, in order to overcome the pressures of fluctuating demographies in both the human and edible plant populations. This study presumes these behavioural adaptations relied on a suite of actions and responses to ecological conditions, passed down the generations since the emergence of targeted plant foods procurement. The main targets, recognisable in the archaeological record, were to reduce the logistical costs, improve the ability for longer-term storage and increase yields per hour of invested labour. I hypothesise that modification of plant habitats was part of this development through activities such as: weeding, selective sowing and altering germination, moisture, soil fertility and light regimes. The carbonised plant assemblage of Chogha Golan and coeval sites in Southwestern Asia, with Ohalo II, Ghar-e Boof and Kebara as Palaeolithic outliers, were examined for signs of these activities. From ordination and cluster plots made, together with comparative analyses of the identified plant taxa, those assemblages near to 11000 years old resembled the earlier Palaeolithic sites in their diversity of edible plants. Before cultivation and gathering storable and seasonal high yielding taxa developed, wild exploitation focussed on breadth in foraging as a guard against the risk of unstable returns. During the adoption of longer residence in the landscape, the ensuing economisation on logistic costs affected the selection of gathered species, yet wild legumes and grasses did not diminish in ubiquity in the studied samples. I suggest the later cultivation of a domesticated emmer was dependent on the local plant ecology, the inhabitants' altered migration patterns, mode of residence and hunting-gathering strategies. In sum, this study suggests that the people occupying Chogha Golan experimented with cultivation, as indicated for example by the triticoid-types found, but subsisted as the Rostamians did 25000 years earlier from local foraging with a greater focus on high yield plants.

\section{Acknowledgements}

Many thanks to my father, my supervisor: Simone Riehl, for her guidance and comments and Anna Florin, Andrew Kandel and Claire Barrett for reading the final draft.

\section{References}

Abbo, S. et al. (2008). Wild lentil and chickpea harvest in Israel: bearin on the origins of Near Eastern farming. Journal of Archaeological Science, 35, 3172-3177. http://dx.doi.org/10.1016/j.jas.2008.07.004

Abbo, S. et al. (2013). Six seasons of wild pea harvest in Israel: bearing on Near Eastern plant domestication. Journal of Archaeological Science, 40, 2095-2100. http://dx.doi.org/10.1016/j.jas.2012.12.024

Albert, R. M., Weiner, S., Bar-Yosef, O., \& Meignen, L. (2000). Phytoliths in the Middle Palaeolithic deposits of Kebara Cave, Mount Carmel, Israel: study of the plant material used for fuel and other purposes. Journal of Archaeological Science, 27, 931-947. http://dx.doi.org/10.1006/jasc.2000.0507

Baines, J., Riehl, S., Conard, N., \& Zeidi, M. (2014). Upper Palaeolithic archaeobotany of Ghar-e Boof cave, Iran: a case study in site disturbance and methodology. Journal of Archaeology and Anthropology Science. http://dx.doi.org/ 10.1007/s12520-014-0191-6

Barlow, K. (2002). Predicting maize agriculture among the Fremont: An economic comparison of farming and foraging in the American Southwest. American Antiquity, 67, 65-87.

Bar-Matthews M., Avner Ayalon L., Kaufman A., \& Wasserburg G. (1998). The Eastern Mediterranean paleoclimate as a reflection of regional events: Soreq cave, Israel. Earth and Planetary Science letters, 166, 85-95

Bar-Yosef, O., \& Goring-Morris, A. (1977). Geometric Kebaran A occurrences. In Prehistoric investigations in Gebel Maghara, Northern Sinai Qedem. Bar-Yosef, O. and Phillips, J. eds. 115-149. Jerusalem: Monographs of the Institute of Archaeology 7.

Bottema S. (2002). The use of palynology in tracing early agriculture. In The dawn of farming in the Near East, Studies in Early Near Eastern Production, Subsistence, and Environment 6. Cappers R. and Bottema, S. eds. 27-38. Berlin: Ex Oriente.

Bottema, S. (1993) The Palaeoenvironment of prehistoric man in the Near East: some aspects of palynological research. Japan Review, 4, 129-149.

Broughton, J., Cannon, M., \& Bartelink, E. (2010). Evolutionary Ecology, Resource Depression, and Niche Construction Theory: Applications to Central California Hunter-Gatherers and Mimbres-Mogollon Agriculturalists. 
Journal Archaeology Method \& Theory, 17, 371-421. http://dx.doi.org/10.1007/s10816-010-9095-7

Byrd, B. (2005). Reassessing the Emergence of Village Life in the Near East. Journal of Archaeological Research, 231-290. http://dx.doi.org/10.1007/s10814-005-3107-2

Colledge, S. \& Conolly, J. (2010). Reassessing the evidence for the cultivation of wild crops during the Younger Dryas at Tell Abur Hureyra, Syria. Environmental Archaeology, 124-138.

Colledge, S. (2002). Identifying pre-domestication cultivation in the archaeobotanical record using multivariate analysis: Presenting the case for quantification. In The Dawn of Farming in the Near East, Studies in Early Near Eastern Production, Subsistence, and Environment 6. Cappers, R. and Bottema, S. eds. 141-152. Berlin: Ex Oriente.

Colledge, S., Conolly, J., \& Shennan, S. (2004). Archaeobotanical evidence for the spread of farming in the Eastern Mediterranean. Current Anthropology, 45/S4, 35-58.

Conard, N., \& Ghasidian, E. (2011). The Rostamian cultural group and the taxonomy of the Iranian Upper Palaeolithic. In Festschrift in honour of Hans-Peter Uerpmann between sand and sea. Conard, N., Drechsler, P. and Morales, A. Eds., 33-52. Tübingen: Kerns.

Diaz, A., O'Connell, T., Maher, L., \& Stock, J. (2012). Subsistence and mobility strategies in the Epipalaeolithic: a stable isotope analysis of human and faunal remains at 'Uyun al-Hammam, northern Jordan. Journal of Archaeological Science, 30, 1-9. http://dx.doi.org/10.1016/j.jas.2012.02.034

Djamali, M. (2008). A late Pleistocene long pollen record from Lake Urmia, NW Iran. Quaternary Research, 69, 413420. http://dx.doi.org/10.1016/j.yqres.2008.03.004

Djamali, M. et al. (2011). Pollen analysis of coprolites from a late Pleistocene/Holocene cave deposit (Wezmeh Cave, west Iran): insights into the late Pleistocene and late Holocene vegetation and flora of the central Zagros Mountains. Journal Archaeological Science, 38, 3394-3401. http://dx.doi.org/10.1016/j.jas.2011.08.001

Dubreuil, L. (2004). Long-term trends in Natufian subsistence: a use-wear analysis of ground stone tools. Journal Archaeological Science, 31, 1613-1629. http://dx.doi.org/10.1016/j.jas.2004.04.003

Edwards, P., Sayej, G., Meadows, J., \& Westaway, M. (2004). From the PPNA to the PPNB: new views from the Southern Levant after excavations at Zahrat adh-Dhra'2 in Jordan. Paléorient, 30/2, 21-60. http://dx.doi.org/ 10.3406/paleo.2004.1010

Fairbairn, A., Martinoli, D., Butler, A., \& Hillman, G. (2007). Wild plant seed storage at Neolithic Çatalhöyük East, Turkey. Vegetation History and Archaeobotany, 16, 467-479. http://dx.doi.org/10.1007/s00334-006-0069-3

Fuller, D. (2007). Contrasting patterns in crop domestication and domestication rates: recent archaeobotanical insights from the old world. Annals of Botany, 100, 903-924. http://dx.doi.org/10.1093/aob/mcm048

Fuller, D., Asouti, E., \& Purugganan, M. (2012a). Cultivation as slow evolutionary entanglement: comparative data on rate and sequence of domestication. Vegetation History and Archaeobotany, 21, 131-145. http://dx.doi.org/10.1007/s00334-011-0329-8

Fuller, D., Willcox, G., \& Allaby, R. (2012b). Early agricultural pathways: moving outside the 'core area' hypothesis in Southwest Asia. Journal of Experimental Botany, 63/2, 617-633. http://dx.doi.org/10.1093/jxb/err307

Garrard, A., Colledge, S., Hunt, C., \& Montague, R. (1988). Environment and subsistence during the late Pleistocene and early Holocene in the Azraq basin. Palórient, 14/2, 40-49.

Ghasidian, E. (2014). Early Upper Palaeolithic occupation at Ghar-e Boof cave; a reconstruction of Cultural tradition in Southern Zagros Mountains of Iran. Tübingen: Kerns.

Hammer, Ø., Harper, D., \& Ryan P. (2001). PAST: Paleontological Statistics Software Package for Education and Data Analysis. Palaeontologia Electronica 4/1.

Hardesty, D. (1975). The Niche Concept: suggestions for its use in human ecology. Human Ecology, 3/2/19: 71-85.

Hayden B. (1990). Nimrods, Piscators, Pluckers, and Planters: The emergence of Food Production. Journal of Anthropological Archaeology, 9, 31-69.

Henry, A., Brooks, A., \& Piperno, D. (2011). Microfossils in calculus demonstrate consumption of plants and cooked foods in Neanderthal diets (Shanidar III, Iraq; Spy I and II, Belgium). Proceedings of the National Academy of Science, 108/2: 486-491. www.pnas.org/cgi/doi/10.1073/pnas.1016868108

Heydari-Guran, S. (2007). The impact of geology and geomorphology on cave and rockshelter archaeological site formation, preservation and distribution in the Zagros Mountains of Iran. Jouranal of Geoarchaeology, 653-669. 
Heydari-Guran, S. (2014). Palaeolithic landscapes of Iran. Tübingen: Kerns.

Hillman, G. et al. (2001). New evidence of lateglacial cereal cultivation at Abu Hureyra on the Euphrates. The Holocene, 383-393.

Hole, F., \& Woosley, A. (1978). Pollen evidence of subsistence and environment in ancient Iran. Paléorient, 4, 59-70.

Hopf, M., \& Bar-Yosef, O. (1987). Plant remains from Hayonim cave, Western Galilee. Paléorient, 117-120.

Jones, C., Lawton, J., \& Shachak, M. (1994). Organisms as ecosystem engineers. OIKOS, 69, 373-386.

Kaufman, D. (1992). Hunter-gatherers of the Levantine Epipalaeolithic: the Socio- logical origins of sedentism. Journal of Mediterranean Archaeology, 5, 165-201.

Kingwell-Banham, E., \& Fuller, D. (2012). Shifting cultivators in South Asia: Expansion, marginalisation and specialisation over the long term. Quaternary International, 249, 84-95. http://dx.doi.org/10.1016/j.quaint.2011.05.025

Kislev, M., \& Bar-Yosef, O. (1988). The legumes: the earliest domesticated plants in the Near East? Current Anthropology, 29, 175-179.

Kislev, M., Hartmann, A., \& Bar-Yosef, O. (2006). Early domesticated fig in the Jordan Valley. Science, 312, 13721374. http://dx.doi.org/10.1126/science.1125910

Kislev, M., Nadel, D., \& Carmi, I. (1992). Epipalaeolithic cereal and fruit diet at Ohalo II, Sea of Galilee, Israel. Review of Palaeobotany and Palynology, 73, 161-167.

Kislev, M., Weiss, E., \& Hartmann, A. (2004). Impetus for sowing and the beginning of agriculture: ground collecting of wild cereals. Proceedings of the National Academy of Science, 2692-2695.

Ladizinsky, G. (1987). Pulse domestication before cultivation. Economic Botany, 41, 60-65.

Laland, K., \& O’ Brien, M. (2010). Niche construction theory and archaeology. Journal Archaeology Method Theory, 17, 303-322. http://dx.doi.org/10.1007/s10816-010-9096-6

Lev, E., Kislev, M., \& Bar-Yosef, O. (2005). Mousterian vegetal food in Kebara cave, Mt. Carmel. Journal Archaeological Science, 32, 475-484.

Madella, M., \& Jones, M. (2002). The exploitation of plant resources by Neanderthals in Amud cave: the evidence from Phytolith studies. Journal Archaeological Science, 29, 703-719.

Martinoli, D., \& Jacomet, S. (2004). Identifying endocarp remains and exploring their use at Epipalaeolithic Üküzini in southwest Anatolia, Turkey. Vegetation History and Archaeobotany, 13, 45-54.

Melamed, Y., Plitmann, U., \& Kislev, M. (2008).Vicia peregrina: an edible early Neolithic legume. Vegetation History Archaeobotany, 17, 29-34.

Moslimany, A. (1987). The late Pleistocene climates of the Lake Zeribar region. Vegetation History and Archaeobotany, 72, 131-139.

Munro, N. (2003). Small game, the younger dryas and the transition to agriculture in the southern levant. Mitteilungen der Gesellschaft für Urgeschichte, 12, 47-71.

Nadel, D. et al. (2004). Stone Age hut in Israel yields world's oldest evidence of bedding. Proceedings of the National Academy of Science, 6821-6826.

Noy, T. (1989). Gilgal 1: a Pre-Pottery Neolithic site, Israel (The 1985-1987 seasons). Paléorient, 11-18.

Odling-Smee, F., Laland, K., \& Feldman, M. (2003). Niche construction: the neglected process in evolution. Monographs in popular biology, 37.

Phillips, J. (1988). The Upper Palaeolithic of the Wadi Feiran, Southern Sinai. Paléorient, 183-200.

Riehl, S. et al. (2011). Plant use in three pre-pottery Neolithic sites of the northern and eastern Fertile Crescent: a preliminary report. Vegetation History and Archaeobotany, http://dx.doi.org/ 10.1007/s00334-011-0318-y.

Riehl, S., Zeidi, M., \& Conard, N. (2013). Emergence of Agriculture in the foothills of the Zagros Mountains of Iran. Science, 65-67. http://dx.doi.org/ 10.1126/science.1236743

Riel-Salvatore, J. (2010). A Niche Construction Perspective on the Middle-Upper Paleolithic Transition in Italy. Journal Archaeology Method Theory, 17. http://dx.doi.org/ 10.1007/s10816-010-9093-9

Rosen, A., \& Rivera-Collazo, I. (2012). Climate Change, adaptive cycles and the persistence of foraging economies during the late Pleistocene/Holocene transition in the Levant. Proceedings of the National Academy of Science, 
3640-3645. www.pnas.org/cgi/doi/10.1073/pnas.1113931109

Rosenberg, M., Nesbitt, R., Redding, R., \& Peasnall, B. (1998.) Hallan Çemi, pig husbandry and post Pleistocene adaptations along the Taurus-Zagros Arc. Paléorient, 25-41.

Rowley-Conwy, P., \& Layton, R. (2011). Foraging and farming as niche construction: stable and unstable adaptations. Philosophical Transactions Royal Society B, http://dx.doi.org/ 10.1098/rstb.2010.0307.

Savard, M., Nesbitt, M., \& Gale, R. (2003). Archaeobotanical evidence for early Neolithic diet and subsistence at M'lefaat (Iraq). Paléorient, 29, 93-106.

Savard, M., Nesbitt, M., \& Jones, M. (2006). The role of wild grasses in subsistence and sedentism: new evidence from the northern Fertile Crescent. World Archaeology, 179-196.

Severinghaus, J. P., Sower, T., Brook, E. J., Alley, R. B., \& Bender, M. L. (1998). Timing of abrupt climate change at the end of the Younger Dryas interval from thermally fractionated gases in polar ice. Nature, 391, 141-146.

Stevens, L., Wright Jr, H., \& Ito, E. (2001). Proposed changes in seasonality of climate during the Lateglacial and Holocene at Lake Zeribar, Iran. The Holocene, 747-755.

Stutz, A., Munro, N., \& Bar-Oz, G. (2009). Increasing the resolution of the Broad Spectrum Revolution in the Southern Levantine Epipaleolithic (19-12 ka). Journal of Human Evolution, 30, 1-13.

Tanno, K., \& Willcox, G. (2006). The origins of cultivation of Cicer arietinum L. and Vicia faba L.: early finds from Tell el-Kerkh, north-west Syria, late 10th millennium B.P. Vegetation History and Archaeobotany, 15, 197-204.

van Zeist, W. (1967). Late Quaternary vegetation history of Western Iran. Review of Palaeobotany and Palynology, 2, 301-311.

van Zeist, W. (2001). Third to first millennium BC plant cultivation on the Khabur, North-Eastern Syria. Palaeohistoria, 41/42, 111-121.

van Zeist, W. (2008). Outline of the vegetation of western Iran. In The Palaeoecology of Lake Zeribar and surrounding areas, Western Iran, during the last 48,000 years. Wasylikowa, K. and Witkowski, A. eds. Diatom Monographs 8, 23-30.

van Zeist, W., Smith, P., Palfenier-Vegter, F., Suwijn, M., \& Casparie, W. (1984). An archaeobotanical study of Ganj Dareh Tepe, Iran. Palaeohistoria, 26, 201-224.

Wasylikowa. K. (2005). Palaeoecology of Lake Zeribar, Iran, in the Pleniglacial, Lateglacial and Holocene, reconstructed from plant macrofossils. The Holocene, 15, 720-735.

Weiss, E., Wetterstrom, W., Nadel, D., \& Bar-Yosef, O. (2004). The broad spectrum revisited: evidence from plant remains. Proceedings of the National Academy of Science, 101/26, 9551-9555. http://dx.doi.org/10.1073/pnas.0402362101

Willcox G. (2013). The roots of cultivation in Southwestern Asia. Science, reports, 341, 39. http://dx.doi.org/ $10.1126 /$ science. 1240496

Willcox, G. (1996). Evidence for plant exploitation and vegetation history from three Early Neolithic pre-pottery sites on the Euprates (Syria). Vegetation History and Archaeobotany, 5, 143-152.

Willcox, G., Buxo, R., \& Herveux, L. (2009). Late Pleistocene and early Holocene climate and the beginnings of cultivation in northern Syria. The Holocene, 151-158. http://dx.doi.org/ 10.1177/0959683608098961

Willcox, G., Fornite, S., \& Herveux, L. (2008). Early Holocene cultivation before domestication in Northern Syria. Vegetation History and Archaeobotany, 17, 313-325. http://dx.doi.org/10.1007/s00334-007-0121-y

Zohary, D., \& Hopf, M. (1973). Domestication of Pulses in the Old World, Science, 182, 887-894.

Zohary, D., Hopf, M., \& Weiss, E. (2012) Domestication of plants in the Old World, fourth edition, 1-7. Oxford University Press. 


\section{Appendix.}

A list of the plant remains identified by the author from Chogha Golan horizon XI. Central Zagros Mountains, Iran.

The taxa are ordered alphabetically by family. Each sample had the same 20 liter volume. They are further subdivided by excavation square (1 meter squares). The plant remains were analyzed and are stored at Tübingen University, Germany.

\begin{tabular}{|c|c|c|c|c|c|c|}
\hline square number & $1 \# 9$ & $1 \# 10$ & $0 \# 0$ & $0 \# 99$ & $0 \# 1$ & $1 \# 1$ \\
\hline amount of samples & 2 & 3 & 6 & 8 & 3 & 3 \\
\hline Pistacio whole nut & 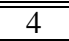 & 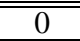 & 3 & 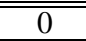 & 1 & 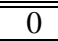 \\
\hline Asteraceae / Cyperaceae & 0 & 5 & 0 & 0 & 2 & 2 \\
\hline Anthemis / Aster & 1 & 0 & 0 & 0 & 0 & 0 \\
\hline Artemisia & 0 & 0 & 0 & 0 & 3 & 0 \\
\hline Carthamus & 2 & 0 & 1 & 0 & 0 & 0 \\
\hline Centaurea & 4 & 9 & 4 & 0 & 0 & 3 \\
\hline Asteraceae indeterminable & 7 & 1 & 9 & 4 & 8 & 3 \\
\hline Heliotropium europeum & 12 & 30 & 21 & 2 & 21 & 16 \\
\hline Echium Vulgare & 0 & 1 & 2 & 0 & 1 & 0 \\
\hline Lepidium & 0 & 0 & 0 & 0 & 0 & 1 \\
\hline Brassicaceae indeterminable & 3 & 4 & 1 & 1 & 5 & 2 \\
\hline Capparis & 4 & 2 & 2 & 1 & 2 & 1 \\
\hline Caryophyllaceae / Malvaceae & 1 & 0 & 0 & 0 & 0 & 0 \\
\hline Caryophyllaceae / Chenopodiaceae & 1 & 1 & 0 & 0 & 3 & 0 \\
\hline Cerastium/Gypsophila/Stellaria & 54 & 91 & 26 & 4 & 62 & 39 \\
\hline Gypsophila & 88 & 181 & 51 & 11 & 114 & 36 \\
\hline Caryophyllaceae indeterminable & 10 & 17 & 5 & 0 & 30 & 4 \\
\hline Lychnis / Silene & 1 & 0 & 0 & 0 & 0 & 0 \\
\hline Sagina & 0 & 0 & 1 & 0 & 0 & 0 \\
\hline Silene & 7 & 7 & 3 & 1 & 16 & 5 \\
\hline Spergula & 0 & 4 & 1 & 0 & 0 & 0 \\
\hline Spergularia & 0 & 0 & 2 & 0 & 0 & 0 \\
\hline Atriplex & 1 & 1 & 4 & 0 & 3 & 0 \\
\hline Atriplex / Chenopodium & 7 & 30 & 16 & 2 & 12 & 4 \\
\hline Chenopodium & 10 & 21 & 6 & 4 & 27 & 8 \\
\hline Halimione & 0 & 0 & 1 & 0 & 0 & 0 \\
\hline Chenopodiaceae indeterminable & 10 & 12 & 13 & 0 & 42 & 12 \\
\hline Salsola & 5 & 10 & 8 & 2 & 5 & 4 \\
\hline Salsola laricina & 3 & 0 & 1 & 2 & 0 & 2 \\
\hline Salsola -type & 2 & 4 & 8 & 0 & 1 & 0 \\
\hline Suaeda & 2 & 16 & 2 & 2 & 4 & 3 \\
\hline Juniperus & 3 & 0 & 0 & 0 & 0 & 0 \\
\hline Scirpus & 39 & 71 & 90 & 21 & 40 & 41 \\
\hline Cypereaceae indet. & 2 & 0 & 0 & 0 & 0 & 1 \\
\hline Astragalus/Trigonella $<1 \mathrm{~mm}$ & 83 & 107 & 34 & 27 & 195 & 37 \\
\hline Astragalus/Trigonella $>1.5 \mathrm{~mm}$ & 253 & 132 & 263 & 78 & 145 & 73 \\
\hline Astragalus/Trigonella $1-1.5 \mathrm{~mm}$ & 609 & 1039 & 927 & 172 & 1353 & 685 \\
\hline cf. Pisum & 26 & 11 & 39 & 4 & 7 & 0 \\
\hline Fabaceae indeterminable & 83 & 94 & 92 & 29 & 53 & 82 \\
\hline Lathyrus / Vicia & 34 & 49 & 42 & 18 & 69 & 22 \\
\hline Lens & 14 & 17 & 24 & 11 & 43 & 23 \\
\hline Medigaco/Trifolium < $1 \mathrm{~mm}$ & 63 & 107 & 57 & 21 & 125 & 37 \\
\hline Medicago/Trifolium > $1.5 \mathrm{~mm}$ & 96 & 80 & 53 & 24 & 90 & 26 \\
\hline Medicago/Trifolium $1-1.5 \mathrm{~mm}$ & 345 & 451 & 407 & 84 & 751 & 199 \\
\hline Medicago radiata & 26 & 20 & 16 & 6 & 20 & 9 \\
\hline Melilotus & 0 & 0 & 0 & 4 & 0 & 1 \\
\hline Pisum & 4 & 12 & 12 & 2 & 23 & 1 \\
\hline Trifolium & 1 & 0 & 0 & 0 & 0 & 0 \\
\hline Trigonella astroites -type & 50 & 59 & 34 & 32 & 156 & 64 \\
\hline Fumaria densiflora & 1 & 0 & 0 & 0 & 1 & 1 \\
\hline Gentianella & 0 & 2 & 0 & 0 & 1 & 0 \\
\hline Erodium & 6 & 7 & 17 & 6 & 9 & 8 \\
\hline Capparis / Salsola & 0 & 1 & 1 & 1 & 0 & 0 \\
\hline Lamiaceae indeterminable & 0 & 1 & 1 & 0 & 2 & 0 \\
\hline Lamium & 2 & 0 & 0 & 0 & 0 & 1 \\
\hline Bellevalia & 1 & 0 & 2 & 3 & 4 & 1 \\
\hline Liliaceae indeterminable & 4 & 2 & 3 & 2 & 8 & 6 \\
\hline Ornithogalum & 3 & 2 & 1 & 0 & 0 & 0 \\
\hline Malva & 20 & 24 & 48 & 8 & 51 & 13 \\
\hline Ficus & 0 & 0 & 0 & 0 & 1 & 0 \\
\hline Glaucium & 0 & 1 & 0 & 0 & 0 & 0 \\
\hline Papaveraceae indeterminable & 0 & 2 & 1 & 0 & 0 & 0 \\
\hline Plantaginaceae indeterminable & 0 & 0 & 0 & 0 & 2 & 0 \\
\hline
\end{tabular}




\begin{tabular}{|c|c|c|c|c|c|c|}
\hline Poaceae < $1 \mathrm{~mm}$. & 5 & 34 & 64 & 15 & 80 & 64 \\
\hline Poaceae > $3 \mathrm{~mm}$. & 122 & 236 & 492 & 61 & 362 & 266 \\
\hline Poaceae $1.5-2.5 \mathrm{~mm}$. & 145 & 481 & 703 & 175 & 593 & 956 \\
\hline Aegilops & 37 & 29 & 80 & 44 & 62 & 19 \\
\hline Aeluropus & 0 & 0 & 0 & 0 & 1 & 0 \\
\hline Agropyron & 0 & 0 & 1 & 1 & 2 & 0 \\
\hline Alopecurus & 0 & 0 & 0 & 1 & 1 & 0 \\
\hline Alopecurus / Phalaris & 6 & 4 & 11 & 0 & 6 & 1 \\
\hline Arrhenatherum & 0 & 4 & 0 & 0 & 0 & 0 \\
\hline Bromus & 0 & 12 & 3 & 3 & 0 & 10 \\
\hline cf. Hordeum & 54 & 115 & 236 & 7 & 88 & 35 \\
\hline Eragrostis / Phleum & 1 & 0 & 0 & 0 & 4 & 0 \\
\hline Chrysopogon / Helictotrichon & 0 & 1 & 0 & 0 & 0 & 0 \\
\hline Hordeum & 126 & 186 & 271 & 105 & 304 & 160 \\
\hline Hordeum / Triticum & 10 & 3 & 5 & 2 & 5 & 1 \\
\hline Lolium temulentum & 0 & 0 & 0 & 0 & 0 & 1 \\
\hline Lolium & 0 & 0 & 0 & 3 & 3 & 1 \\
\hline Phalaris & 33 & 56 & 17 & 6 & 54 & 21 \\
\hline Phleum & 0 & 0 & 0 & 0 & 8 & 0 \\
\hline Stipa & 0 & 0 & 0 & 1 & 0 & 0 \\
\hline Taeniatherum & 27 & 29 & 19 & 24 & 33 & 33 \\
\hline triticoid -type & 68 & 64 & 79 & 38 & 96 & 33 \\
\hline Rumex & 0 & 0 & 0 & 0 & 1 & 0 \\
\hline Persicaria & 0 & 0 & 0 & 0 & 1 & 0 \\
\hline Polygonaceae indet. & 1 & 0 & 0 & 0 & 0 & 0 \\
\hline Adonis & 0 & 0 & 3 & 0 & 2 & 1 \\
\hline Ranunculaceae indet. & 0 & 0 & 1 & 0 & 0 & 0 \\
\hline Ranunculus & 0 & 0 & 1 & 0 & 0 & 0 \\
\hline Ranunculaceae / Solanaceae & 0 & 0 & 1 & 0 & 0 & 1 \\
\hline Reseda luteola & 2 & 2 & 10 & 0 & 5 & 0 \\
\hline Rubiaceae indeterminable & 1 & 0 & 1 & 0 & 0 & 0 \\
\hline Galium & 9 & 32 & 19 & 3 & 24 & 9 \\
\hline Asperula / Galium & 0 & 0 & 1 & 0 & 0 & 0 \\
\hline Scrophulariaceae & 1 & 0 & 0 & 0 & 0 & 2 \\
\hline Solanum & 1 & 0 & 1 & 0 & 0 & 0 \\
\hline
\end{tabular}

\section{(cc) EY}

This work is licensed under a Creative Commons Attribution 3.0 License. 